\title{
Türkiye’deki Fen Bilimleri Öğretmenliği Programlarının Genel Durumlarının ve Atama Sayılarının İncelenmesi
}

\author{
Tuğba TAFLI*
}

ÖZ

Bu çalışmanın amacı Türkiye'deki Eğitim Fakülteleri'nde bulunan Fen Bilimleri Öğretmenliği programlarının son 5 ylldaki genel durumunun incelenmesidir. Çalışmada doküman incelemesi yöntemi kullanılmıș olup, 2016-2020 yıllarına ait ÖSYM tarafindan ilan edilen ilk yerleştirme ve ek yerleştirme sonuçlarına göre fen bilimleri öğretmenliği programları içerik analizi tekniğine göre düzenlenmiştir. Bu kapsamda fen bilgisi öğretmenliği, biyoloji öğretmenliği, fizik öğretmenliği ve kimya öğretmenliği bölümlerine ilişkin; hangi üniversitelerde bulunduğu, genel kontenjan sayıları, Yükseköğretim Kurumları Sınavı (YKS) sonuçlarına göre bu programlara yerleștirilen öğrenci savıları ile her üniversite bazındaki doluluk oranları yıllara göre ayrı ayrı hesaplanarak ortaya konmuştur. Çalışmada ayrıca Milli Ĕ̆itim Bakanlığı (MEB) tarafından fen bilimleri öğretmeni kadrolarına yönelik yapılan öğretmen atama sayıları da yine aynı yıllar ile sınırlandırılarak incelenmiştir. Yapılan incelemeler sonucunda üniversitelerdeki fen bilimleri öğretmenliklerinin hepsinde genel kontenjan sayılarında son 5 yll içerisinde oldukça fazla oranda azalma olduğu görülmüştür. Öğrencilerin üniversiteye giriş sınavı sonuçlarına göre ilgili programların doluluk oranları incelendiğinde ise tüm branşlarda 2016 yllında \%100 oranına sahipken; 2017 yllından sonra uygulamaya konulan üniversite sınav sonucundaki başarı sıralaması şartı ile birlikte 2017 ve 2018 yıllarında ilgili programlara yerleşen öğrencilerin doluluk oranlarında düşüş yaşanmıştır. Doluluk oranlarındaki azalmaya bağlı olarak kontenjan sayıları da azaltılan her bir fen bilimleri öğretmenliği programlarının 2019 yılında doluluk oranının yeniden artma eğilimine geçtiği, 2020 yılı itibari ile ise yeniden tam kapasite doluluk oranına ulaştı̆̆ tespit edilmiştir.

Anahtar Kelimeler: Fen bilimleri öğretmenliği programları, Lisans kontenjanları, Program doluluk oranları, Öğretmen atamalar1

\section{Examination of the General Situation of Science Education Programs and Teacher Appointments of Turkey}

\begin{abstract}
The aim of this study is to determine the general situation of the Science Education Programs of all universities in Turkey about the last 5 years. Document analysis method, the first placement and additional placement tables announced by OSYM for the years of 2016-2020, was used in the study and the results of all science teaching programs data were organized according to the content analysis tecnique. In this context, regarding the departments of science education, biology education, physics education and chemistry education were organized separately by years about in which universites has these programs, the number of their general quotas, the number of students placed in these programs and the occupancy rates on each universities. The number of teacher appointments made by the Ministry of National Education (MEB) for science teachers was also examined by limiting it to the same years. As a result of the analysis, it has been observed that the general quota of all science education programs has decreased considerably in the last 5 years. The occupancy rates of the students who were placed in the relevant programs in 2017 and 2018 decreased with the success ranking condition that was implemented after 2017, which was almost $100 \%$ in 2016 in all branches of science education. Due to the reduced occupancy of the programs and the quotas, the results showed that the occupancy rates was started to increase in 2019 and the occupancy rate reached full capacity again as of 2020.

Keywords: Science education programs, Undergraduate quotas, Program occupancy rates, Teacher appointments
\end{abstract}

\section{Giriş}

Eğitim şüphesiz her ülkenin gelişmesinde ve kalkınmasında temel oluşturan en önemli hususların başında gelmektedir. Ülkemizde de eğitim kalitesinin artırılmasına yönelik çeşitli bilimsel çalışmalar yapılmaktadır. Eğitimde; toplumun gereksinimleri doğrultusunda bilgi toplumlarının özellikleri dikkate alınarak bireylerin yetiştirilmesi zorunluluğu ortaya çıkmıştır (Aydın, 2003). İçinde bulunduğumuz yüzyılda hızlı bir şekilde gelişimine ve değişimine devam eden bilgi ve iletişim teknolojileri ile birlikte tüm dünyada olduğu gibi ülkemizde de tüm bireylerin farklı bilgi ve becerilere sahip olması gerekliliğini ortaya çıkmıştır. OECD (2018), öğrencilerin gelecek dönemlerde sosyal ve dijital alanlardaki değişimlere uyum kabiliyetlerini artırmak amacıyla bilgi, beceri, tutum ve değerler açısından sahip olmaları gereken

* Dr., Selçuk Üniversitesi, tugbatafli@gmail.com

Makalenin Gönderim Tarihi: 10.04.2021; Makalenin Kabul Tarihi: 06.10.2021 
becerilerini dönüşümcü yeterlikler olarak sunmaktadır. Öğrencilerin eleştirel düşünme, yenilikçi düşünme, öğrenmeyi öğrenme ve öz-düzenleme becerilerinin yanı sıra empati, öz-yeterlilik, işbirliği, pratik beceriler, motivasyon, güven, erdemli olma gibi pek çok özelliğe sahip olmaları gerektiğini ve disiplinlerarası bilgiyle donanılmaları gerektiğine vurgu yapmaktadır. Benzer şekilde Dünya Ekonomi Forumu(WEF- World Economic Forum) tarafindan bireylerin sahip olmaları gereken 10 temel beceri olarak; karmaşık problem çözme, analitik ve eleştirel düşünme, yaratıcılık, yönetim, kişiler arası koordinasyon, duygusal zekâ, değerlendirme ve karar alma, hizmet odaklılık, müzakere ve bilişsel esneklik becerileri olarak belirlenmiştir (Gray, 2016). Çağın gerektirdiği değişikliklere ve yeniliklere açık olan, bunlara uyum sağlayan ve günlük hayata transfer edebilen bireylerin eğitim öğretim sürecinde yetiştirilmesi önem kazanmıştır. Bu bakımdan öğrencilerin, okul bilgilerinin günlük yaşamla bağlantılarının farkına vararak günlük yaşama adapte edebilmeleri, herhangi bir problem durumunda çözüm üretebilmeleri, yaratıc1 ve eleştirel düşünme becerilerini geliştirmeleri, bilgi ve iletişim teknolojilerini etkili kullanabilmeleri için yeni yüzyll becerilerine sahip olmaları gerekmektedir.

Eğitim sistemimizin kalitesinin artmasında ve uluslararası standartlara ulaşmamızda eğitimin temel ve göz ardı edilemez en önemli öğesini şüphesiz öğretmenler oluşturmaktadır. Eğitimin kalitesinin artırılması için günümüzün değişen ihtiyaçlarının farkında olan ve bu ihtiyaçlara uygun bir şekilde cevap verebilen öğretmenler yetiştirilmesi gerekmektedir (Magnusson, Krajcik ve Borko, 1999). Eğitimde, öğretmen dışındaki diğer bireylerin de istenilen düzeyde ve nitelikte olması geleceğimize yönelik yapılacak yatırımlarda kilit görevi oluşturmaktadır. Bu nedenle eğitim kurumlarında hem nitelikli öğretmenlerin hem de nitelikli öğrencilerin yetiştirilmesi hususu bir gereklilikten ziyade zorunluluk haline dönüşmüştür. Ülkemizde nitelikli öğretmenlerin yetiştirilmesi amacıyla hem hizmet öncesinde hem de hizmet içinde mesleki yeterliklerinin geliştirilmesi ve artırlması gereklidir (Şişman, 2000). Özellikle hizmet öncesi dönemde öğretmen adaylarının gerek üst düzeyde alan ve pedagojik bilgisine gerekse yeni yüzyıl becerilerine sahip bireyler olarak yetiştirilmesi amacıyla eğitim fakültelerine önemli görevler düşmektedir.

Eğitimin temel alanlarından birisi olan "fen bilimleri eğitimi" ilköğretimden ortaöğretime, ortaöğretimden üniversiteye eğitimin her kademesindeki öğrenciler ve bireyler için son derece önemlidir. Öyle ki sadece ilköğretim dönemindeki öğrenciler için değil daha temel yaşlardaki öğrenciler için de fen derslerine yönelik bilgi, beceri ve farkındalıkların kazandırılması amacıyla için okul öncesi dönemde de çeşitli faaliyetler ile çocuklara fen eğitimi verilmektedir. Fen öğretimi sarmal program ile eğitimin her kademesinde yerini almaktadır. Bu nedenle öğrencilere fen bilimleri derslerinde sadece teorik bilgilerin kazandırılmasının yanı sıra özellikle yeni yüzyıl becerileri ile harmanlanmış bir şekilde bilgileri özümseyen bireylerin yetiştirilmesi önem kazanmaktadır.

Bilindiği üzere uluslararası boyutta ögrencilerin değerlendirilmesine ilişkin PISA ve TIMMS gibi sınavların değerlendirme çıktıları ülkelerin eğitim sistemlerindeki başarı düzeyleri hakkında dönütler vermektedir. Uluslararası Öğrenci Değerlendirme Programı (PISA- Programme for International Student Assessment), Ekonomik İşbirliği ve Kalkınma Örgütü (OECD- Organisation for Economic Co-operation and Development) tarafindan üç yılda bir 15 yaşındaki öğrencilerin kazandıkları bilgi ve becerileri değerlendiren bir araştırmadır. PISA'da öğrencilerin; matematik okuryazarllğı, fen okuryazarlığ1 ve okuma becerilerine yönelik yeterlik düzeyleri ile öğrenme istekleri, öğrenme stratejileri, okul ve aile ortamları ile ilgili verilere ulaşılmaktadır (OECD, 2016). Uluslararası Matematik ve Fen Eğilimleri Araştırması (TIMSSTrends in International Mathematics and Science Study) sinav1 Hollanda merkezli olarak matematik ve fen eğilimlerine yönelik dört yılda bir uygulanan uluslararası bir sınavdır. TIMSS sınavı ile sınava katılan ülkelerin 4. ve 8. sınıf öğrencilerinin bilgi ve becerileri ölçülmektedir (TIMSS, 2018). Dünya çapında uygulanan bu sınavlardan elde edilen sonuçlar ve başarı sıralamaları ülkemizde de oldukça dikkate alınmaktadır. Gerek PISA gerekse TIMMS sınavlarının her ikisinde de öğrencilerin fen bilimleri derslerindeki durum değerlendirme çıktıları elde edilmektedir. Bu çıktılar da fen bilimleri derslerinin önemini ortaya koyan önemli bir gösterge niteliğindedir.

Ülkemizdeki Fen Bilimleri Öğretmenliği programı; Eğitim Fakültelerinin Matematik ve Fen Bilimleri Bölümü altında Fen Bilgisi Eğitimi, Biyoloji Eğitimi, Fizik Eğitimi ve Kimya Eğitimi Ana Bilim Dallarında yürütülmektedir. Fen bilgisi eğitimi programı ilköğretim seviyesindeki öğrencilere yönelik öğretmen yetiştirmeyi hedeflerken; Biyoloji, Fizik ve Kimya öğretmenlikleri ise ortaöğretim seviyesindeki öğrencilere 
yönelik öğretmen yetiştirmeyi hedeflemektedir. Her programda da 4 yılllk lisans eğitimini başarılyla tamamlayarak öğretmen olmaya hak kazanan mezunlar devlet veya özel okullarda öğretmen olarak görev yapmaktadırlar. Ayrıca üniversitelerin akademik kadrolarında da istihdam edilebilmektedirler.

Ülkemizde üniversitelere Ölçme, Seçme ve Yerleştirme Merkezi [ÖSYM] tarafindan yapılan merkezi sınav sonuçlarına ve öğrencilerin yaptığı tercihlere göre öğrenciler yerleştirilmektedir. Daha önce herhangi bir başarı sıralaması şartı bulunmayan eğitim fakülteleri tercihlerine 2016 yllında Yükseköğretim Kurulu [YÖK] tarafından başarı sıralaması şartının 2017 yılından itibaren yapılacağı açıklanmıştır. Buna göre ÖSYM (2017:11) Yükseköğretim Programları ve Kontenjanları Kılavuzunda "Öğretmenlik programlarına yerleştirme işlemlerinde (Rehberlik ve Psikolojik Danışmanlık programı dâhil) İlgili LYS Puan Türünde en düşük 240 bininci” öğrenci alımının yapılacağı bilgisi verilmiştir. Ancak bu say1 2018 yllı ve daha sonrasında ilgili YKS puan türünde en düşük 300 bininci olarak değiştirilmiştir (ÖSYM, 2018a:11; ÖSYM 2019a:11; ÖSYM 2020a:12).

Bu çalışmada; 2016 yılından sonra öğretmenlik programlarına gelen başarı sıralaması kısıtlaması ile son 5 yıl içerisinde Türkiye'deki Fen Bilimleri Öğretmeni yetiştiren Eğitim Fakültelerinin genel durumlarının incelenmesi amaçlanmıştır. Bu kapsamda 2016-2020 yılları arasında ülkemizdeki fen bilgisi öğretmenliği, biyoloji öğretmenliği, fizik öğretmenliği ve kimya öğretmenliği bölümlerinin hangi üniversitelerde bulunduğu, genel kontenjan sayıları, YKS sonuçlarına göre hem ilk hem de ek yerleştirmeler sonucunda bu programlara yerleştirilen öğrenci sayıları sonucundaki doluluk oranları tespit edilmek istenmiştir. Ayrıca son 5 yılda Milli Eğitim Bakanlığı (MEB) tarafından fen bilimleri öğretmenlerinin istihdam sayıları da incelenmiştir.

\section{Araştırma Problemleri}

1- 2016-2020 yılları arasında Fen Bilgisi Öğretmenliği programı bulunan üniversiteler, kontenjanları, ilk ve ek yerleştirme sonucunda kayıt yaptıran öğrenci sayıları ve genel durum tablosu nasıldır?

2- 2016-2020 y1lları arasında Biyoloji Öğretmenliği programı bulunan üniversiteler, kontenjanları, ilk ve ek yerleștirme sonucunda kayıt yaptıran öğrenci sayıları ve genel durum tablosu nasıldır?

3- 2016-2020 yılları arasında Fizik Öğretmenliği programı bulunan üniversiteler, kontenjanları, ilk ve ek yerleştirme sonucunda kayıt yaptıran öğrenci sayıları ve genel durum tablosu nasıldır?

4- 2016-2020 yilları arasında Kimya Öğretmenliği programı bulunan üniversiteler, kontenjanları, ilk ve ek yerleştirme sonucunda kayıt yaptıran öğrenci sayıları ve genel durum tablosu nasıldır?

5- 2016-2020 yılları arasında Fen Bilimleri Öğretmenliği programlarının branş bazındaki ve birbirleriyle olan genel karşılaştırması nasıldır?

6- 2016-2020 y1lları arasında Fen Bilgisi Öğretmenliği, Biyoloji Öğretmenliği, Fizik Öğretmenliği ve Kimya Öğretmenliği MEB atama sayıları nasıldır?

\section{Yöntem}

Bu çalışmada nitel araştırmalarda kullanılan doküman incelemesi yönteminden yararlanılarak 2016-2020 yıllarına ait ÖSYM tarafindan ilan edilen tablolardan fen bilimleri öğretmenliklerine ilişkin veriler kullanılmıştır. Doküman incelemesi ile hem elektronik hem de basilı materyalleri sistematik olarak değerlendirmek için kullanılan uygulamalardan biridir (Bowen, 2009). Doküman incelemesinde araştırılması hedeflenen olgu veya olgular hakkında bilgi içeren yazıllı materyallerin analizi yapıllır, içeriği ise sistematik bir şekilde düzenlenir (Wach, 2013). Ayrıca doküman incelemelesi; eğitim araştırmalarına yönelik belirli bir olguya ilişkin açıklama veya cevap bulmak için en kısa zamanda, minimum emek ve maliyetle gerçekleştirilmesi için yapılan eylemleri kapsamaktadır (Sönmez ve Alacapınar, 2014).

\subsection{Veri toplama araçları}

Bu çalışmada, 2016-2020 yılları arasında ÖSYM tarafindan ilan edilen merkezi yerleştirme ile öğrenci alan yükseköğretim lisans programları tablosunun ilk yerleştirme sonuçlarına göre verilen genel kontenjan sayılarını ve ilgili programlara yerleşen öğrenci sayılarını içeren dokümanlar ile aynı yıllara ait boş kalan kontenjan durumlarına göre açıklanan ek yerleştirme genel kontenjan sayllarnı ve yerleşen öğrenci sayılarını içeren dokümanlar incelenmiştir (ÖSYM, 2016ab; 2017bc; 2018bc; 2019bc; 2020bc; MEB 2016, 
2017, 2018, 2019, 2020). Çalışmanın şeffaflı̆̆1 açısından, incelenen dokümanların listesi Ek bölümünde bildirilmiştir.

\subsection{Verilerin analizi}

$\mathrm{Bu}$ çalışmada, doküman incelemesinden elde edilen verilerin düzenlenmesinde içerik analizi tekniğinden yararlanılmıştır. İçerik analizinde temel amaç, birbirine benzeyen verileri belirli kavramlar ve temalar çerçevesinde bir araya getirmek ve bunları okuyucunun anlayabileceği bir biçimde düzenleyerek yorumlamaktır (Yıldırım ve Şimşek, 2006). Çalışmada, ilgili dokümanlardan Türkiye’deki üniversitelerin Eğitim Fakülteleri'nde bulunan fen bilgisi öğretmenliği, biyoloji öğretmenliği, fizik öğretmenliği ve kimya öğretmenliği programlarının bulunduğu üniversitelere ilişkin veriler incelenmiş olup ilk yerleştirme ve ek yerleştirme sonuçlarına göre yerleşen nihai öğrenci sayıları hesaplanarak yeni tablolar oluşturulmuştur. İlgili programlara yerleşen öğrenci sayılarının genel kontenjanlara göre yerleşme oranları da \% olarak hesaplanarak aynı tabloda gösterilmiştir. Her branşın yıllara göre öğrenci yerleşme yüzdelerine göre oluşturulan genel karşılaştırma tablosu ve grafikleri de ayrı ayrı gösterilmiştir. Son olarak ilgili programların MEB Personel Genel Müdürlügü tarafindan açıklanan 2016-2020 yılları arasındaki öğretmen atama sayılarının yayımlandı̆̆ı dokümanlar da incelenerek ayrı bir tabloda gösterilmiştir.

\section{Bulgular}

1- 2016-2020 yılları arasında Türkiye'deki Eğitim Fakülteleri’nde Fen Bilgisi Öğretmenliği programı bulunan üniversiteler, kontenjan sayıları ile YKS ilk tercih ve ek yerleştirme sonuçlarına göre kayıt yaptıran öğrenci sayılarının düzenlendiği son 5 yıla ait veriler Tablo 1’de gösterilmiştir (ÖSYM, 2016; 2017b,c; 2018 b,c; 2019 b,c; 2020b,c).

Tablo 1: Fen Bilgisi Öğretmenliği programı bulunan Türkiye’deki üniversitelerin 2016-2020 yıllarına ait kontenjanları ve yerleșen öğrencilere ait içerik analizi

\begin{tabular}{|c|c|c|c|c|c|c|c|c|c|c|c|c|c|c|c|}
\hline \multirow[b]{2}{*}{ ÜNİVERSİTE } & \multicolumn{3}{|c|}{2016} & \multicolumn{3}{|c|}{2017} & \multicolumn{3}{|c|}{2018} & \multicolumn{3}{|c|}{2019} & \multicolumn{3}{|c|}{2020} \\
\hline & 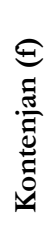 & 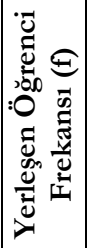 & 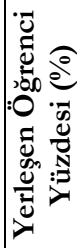 & 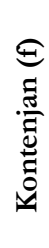 & 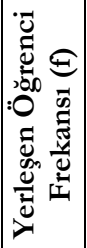 & 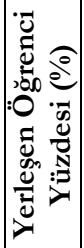 & 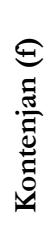 & 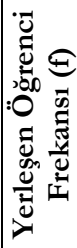 & 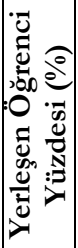 & 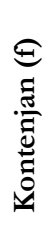 & 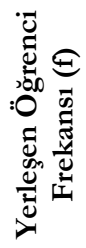 & 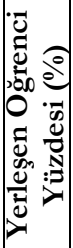 & 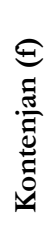 & 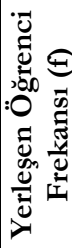 & 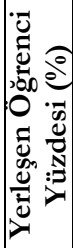 \\
\hline $\begin{array}{l}\text { Abant İzzet Baysal } \\
\text { Üniversitesi }\end{array}$ & 62 & 62 & 100 & 62 & 62 & 100 & 62 & 35 & 56 & 41 & 41 & 100 & 41 & 41 & 100 \\
\hline Adiyaman Üniversitesi & 52 & 52 & 100 & 52 & 52 & 100 & 62 & 13 & 21 & 31 & 31 & 100 & 31 & 31 & 100 \\
\hline $\begin{array}{l}\text { Adnan Menderes } \\
\text { Üniversitesi }\end{array}$ & 52 & 52 & 100 & 52 & 52 & 100 & 62 & 29 & 47 & 36 & 36 & 100 & 36 & 36 & 100 \\
\hline Afyon Kocatepe Üniversitesi & 67 & 67 & 100 & 67 & 67 & 100 & 62 & 8 & 13 & 31 & 31 & 100 & 31 & 31 & 100 \\
\hline $\begin{array}{l}\text { Ağr1 İbrahim Çeçen } \\
\text { Üniversitesi }\end{array}$ & 41 & 41 & 100 & 41 & 5 & 12 & 21 & 7 & 33 & 21 & 3 & 14 & - & - & - \\
\hline Ahi Evran Üniversitesi & 82 & 82 & 100 & 82 & 16 & 20 & 41 & 8 & 20 & 31 & 9 & 29 & 21 & 21 & 100 \\
\hline Akdeniz Üniversitesi & 82 & 81 & 99 & 82 & 82 & 100 & 62 & 62 & 100 & 52 & 52 & 100 & 52 & 52 & 100 \\
\hline Aksaray Üniversitesi & 52 & 52 & 100 & 52 & 21 & 40 & 41 & 13 & 32 & 41 & 31 & 76 & 41 & 41 & 100 \\
\hline $\begin{array}{l}\text { Alanya Alaaddin Keykubat } \\
\text { Üniversitesi }\end{array}$ & 52 & 51 & 98 & 52 & 52 & 100 & 52 & 25 & 48 & 41 & 41 & 100 & 41 & 41 & 100 \\
\hline Amasya Üniversitesi & 93 & 93 & 100 & 93 & 30 & 32 & 52 & 9 & 17 & 31 & 19 & 61 & 31 & 31 & 100 \\
\hline Artvin Çoruh Üniversitesi & 62 & 62 & 100 & 62 & 5 & 8 & 21 & 0 & 0 & - & - & - & - & - & - \\
\hline Atatürk Üniversitesi & 93 & 93 & 100 & 93 & 59 & 63 & 62 & 33 & 53 & 52 & 35 & 67 & 52 & 52 & 100 \\
\hline Balıkesir Üniversitesi & 52 & 52 & 100 & 52 & 51 & 98 & 52 & 52 & 100 & 52 & 52 & 100 & 52 & 52 & 100 \\
\hline Bartın Üniversitesi & 62 & 62 & 100 & 62 & 0 & 0 & 21 & 5 & 24 & 21 & 6 & 29 & 21 & 21 & 100 \\
\hline Bayburt Üniversitesi & 93 & 93 & 100 & 93 & 1 & 1 & 21 & 2 & 10 & - & - & - & - & - & - \\
\hline Boğaziçi Üniversitesi & 52 & 50 & 96 & 52 & 52 & 100 & 52 & 50 & 96 & 52 & 52 & 100 & 52 & 52 & 100 \\
\hline Bozok Üniversitesi & 52 & 52 & 100 & 52 & 9 & 17 & 21 & 2 & 10 & 21 & 8 & 38 & 21 & 21 & 100 \\
\hline Bülent Ecevit Üniversitesi & 52 & 52 & 100 & 52 & 25 & 48 & 41 & 6 & 15 & 31 & 9 & 29 & 21 & 21 & 100 \\
\hline
\end{tabular}




\begin{tabular}{|c|c|c|c|c|c|c|c|c|c|c|c|c|c|c|c|}
\hline Celâl Bayar Üniversitesi & 93 & 93 & 100 & 93 & 69 & 74 & 62 & 9 & 15 & 31 & 21 & 68 & 31 & 31 & 100 \\
\hline Cumhuriyet Üniversitesi & 93 & 93 & 100 & 93 & 37 & 40 & 52 & 20 & 38 & 31 & 31 & 100 & 31 & 31 & 100 \\
\hline $\begin{array}{l}\text { Çanakkale Onsekiz Mart } \\
\text { Üniversitesi }\end{array}$ & 67 & 67 & 100 & 67 & 67 & 100 & 62 & 50 & 81 & 52 & 52 & 100 & 52 & 52 & 100 \\
\hline Çukurova Üniversitesi & 62 & 61 & 98 & 62 & 62 & 100 & 62 & 62 & 100 & 52 & 52 & 100 & 52 & 52 & 100 \\
\hline Dicle Üniversitesi & 41 & 41 & 100 & 41 & 41 & 100 & 41 & 37 & 90 & 41 & 41 & 100 & 41 & 41 & 100 \\
\hline Dokuz Eylül Üniversitesi & 93 & 92 & 99 & 93 & 93 & 100 & 62 & 62 & 100 & 62 & 62 & 100 & 62 & 62 & 100 \\
\hline Dumlupınar Üniversitesi & 52 & 52 & 100 & 52 & 52 & 100 & 52 & 18 & 35 & 31 & 31 & 100 & 31 & 31 & 100 \\
\hline Düzce Üniversitesi & 41 & 41 & 100 & 41 & 24 & 59 & 41 & 6 & 15 & 31 & 14 & 45 & 31 & 31 & 100 \\
\hline Ege Üniversitesi & 52 & 50 & 96 & 52 & 50 & 96 & 52 & 51 & 98 & 52 & 52 & 100 & 52 & 52 & 100 \\
\hline Erciyes Üniversitesi & 72 & 70 & 97 & 72 & 72 & 100 & 62 & 62 & 100 & 52 & 52 & 100 & 52 & 52 & 100 \\
\hline $\begin{array}{l}\text { Erzincan Binali Yıldırım } \\
\text { Üniversitesi }\end{array}$ & 93 & 93 & 100 & 93 & 5 & 5 & 21 & 9 & 43 & 21 & 4 & 19 & 21 & 21 & 100 \\
\hline $\begin{array}{l}\text { Eskişehir Osmangazi } \\
\text { Üniversitesi }\end{array}$ & 62 & 60 & 97 & 62 & 62 & 100 & 62 & 62 & 100 & 62 & 62 & 100 & 62 & 62 & 100 \\
\hline Fırat Üniversitesi & 62 & 62 & 100 & 62 & 62 & 100 & 62 & 19 & 31 & 31 & 31 & 100 & 31 & 31 & 100 \\
\hline Gazi Üniversitesi & 93 & 90 & 97 & 93 & 93 & 100 & 62 & 60 & 97 & 62 & 62 & 100 & 62 & 62 & 100 \\
\hline Gaziosmanpaşa Üniversitesi & 57 & 57 & 100 & 57 & 18 & 32 & 41 & 8 & 20 & 31 & 13 & 42 & 31 & 31 & 100 \\
\hline Giresun Üniversitesi & 88 & 88 & 100 & 88 & 10 & 11 & 41 & 4 & 10 & 31 & 11 & 35 & 31 & 31 & 100 \\
\hline Hacettepe Üniversitesi & 93 & 90 & 97 & 93 & 93 & 100 & 62 & 61 & 98 & 62 & 62 & 100 & 62 & 62 & 100 \\
\hline Harran Üniversitesi & 41 & 41 & 100 & 41 & 41 & 100 & 41 & 32 & 78 & 41 & 41 & 100 & 41 & 41 & 100 \\
\hline İnönü Üniversitesi & 72 & 72 & 100 & 72 & 72 & 100 & 62 & 52 & 84 & 52 & 52 & 100 & 52 & 52 & 100 \\
\hline İstanbul Üniversitesi & 57 & 57 & 100 & 57 & 57 & 100 & 62 & 62 & 100 & 62 & 62 & 100 & 62 & 62 & 100 \\
\hline Kafkas Üniversitesi & 82 & 82 & 100 & 82 & 4 & 5 & 21 & 3 & 14 & 21 & 4 & 19 & 21 & 21 & 100 \\
\hline $\begin{array}{l}\text { Kahramanmaraş Sütçü İmam } \\
\text { Üniversitesi }\end{array}$ & 52 & 52 & 100 & 52 & 52 & 100 & 52 & 32 & 62 & 41 & 41 & 100 & 41 & 41 & 100 \\
\hline $\begin{array}{l}\text { Karadeniz Teknik Trabzon } \\
\text { Üniversitesi }\end{array}$ & 93 & 92 & 99 & 93 & 93 & 100 & 62 & 38 & 61 & 41 & 41 & 100 & 41 & 41 & 100 \\
\hline Kastamonu Üniversitesi & 93 & 93 & 100 & 93 & 24 & 26 & 41 & 3 & 7 & 21 & 6 & 29 & 21 & 21 & 100 \\
\hline Kırıkkale Üniversitesi & 82 & 82 & 100 & 82 & 58 & 71 & 62 & 16 & 26 & 31 & 25 & 81 & 31 & 31 & 100 \\
\hline Kilis 7 Aralık Üniversitesi & 41 & 41 & 100 & 41 & 17 & 41 & 41 & 5 & 12 & 31 & 11 & 35 & 31 & 31 & 100 \\
\hline Kocaeli Üniversitesi & 62 & 60 & 97 & 62 & 62 & 100 & 62 & 62 & 100 & 52 & 52 & 100 & 52 & 52 & 100 \\
\hline Marmara Üniversitesi & 62 & 61 & 98 & 62 & 60 & 97 & 62 & 61 & 98 & 62 & 62 & 100 & 62 & 62 & 100 \\
\hline $\begin{array}{l}\text { Mehmet Akif Ersoy } \\
\text { Üniversitesi }\end{array}$ & 82 & 82 & 100 & 82 & 25 & 30 & 41 & 7 & 17 & 31 & 23 & 74 & 31 & 31 & 100 \\
\hline Mersin Üniversitesi & 52 & 51 & 98 & 52 & 52 & 100 & 52 & 52 & 100 & 41 & 41 & 100 & 41 & 41 & 100 \\
\hline $\begin{array}{l}\text { Muğla Sitk1 Koçman } \\
\text { Üniversitesi }\end{array}$ & 72 & 72 & 100 & 72 & 72 & 100 & 62 & 35 & 56 & 41 & 41 & 100 & 41 & 41 & 100 \\
\hline Mustafa Kemal Üniversitesi & 62 & 62 & 100 & 62 & 62 & 100 & 62 & 37 & 60 & 41 & 41 & 100 & 41 & 41 & 100 \\
\hline Muş Alparslan Üniversitesi & 41 & 41 & 100 & 41 & 7 & 17 & 21 & 2 & 10 & 21 & 6 & 29 & 21 & 21 & 100 \\
\hline $\begin{array}{l}\text { Necmettin Erbakan } \\
\text { Üniversitesi }\end{array}$ & 82 & 82 & 100 & 82 & 82 & 100 & 62 & 62 & 100 & 52 & 52 & 100 & 52 & 52 & 100 \\
\hline $\begin{array}{l}\text { Nevşehir Hacı Bektaş Veli } \\
\text { Üniversitesi }\end{array}$ & 41 & 41 & 100 & 41 & 40 & 98 & 41 & 16 & 39 & 41 & 32 & 78 & 41 & 41 & 100 \\
\hline $\begin{array}{l}\text { Niğde Ömer Halisdemir } \\
\text { Üniversitesi }\end{array}$ & 62 & 61 & 98 & 62 & 38 & 61 & 52 & 13 & 25 & 41 & 41 & 100 & 41 & 41 & 100 \\
\hline Ondokuz Mayıs Üniversitesi & 93 & 93 & 100 & 93 & 93 & 100 & 62 & 62 & 100 & 52 & 52 & 100 & 52 & 52 & 100 \\
\hline Ordu Üniversitesi & 31 & 31 & 100 & 31 & 13 & 42 & 31 & 8 & 26 & 31 & 16 & 52 & 31 & 31 & 100 \\
\hline $\begin{array}{l}\text { Orta Doğu Teknik } \\
\text { Üniversitesi }\end{array}$ & 41 & 40 & 98 & 41 & 41 & 100 & 41 & 41 & 100 & 41 & 41 & 100 & 41 & 41 & 100 \\
\hline Pamukkale Üniversitesi & 93 & 93 & 100 & 93 & 93 & 100 & 62 & 51 & 82 & 52 & 52 & 100 & 52 & 52 & 100 \\
\hline $\begin{array}{l}\text { Recep Tayyip Erdoğan } \\
\text { Üniversitesi }\end{array}$ & 72 & 72 & 100 & 72 & 21 & 29 & 62 & 4 & 6 & 21 & 12 & 57 & 31 & 31 & 100 \\
\hline Sakarya Üniversitesi & 62 & 62 & 100 & 62 & 62 & 100 & 62 & 42 & 68 & 41 & 41 & 100 & 41 & 41 & 100 \\
\hline Siirt Üniversitesi & 82 & 82 & 100 & 82 & 17 & 21 & 41 & 7 & 17 & 31 & 18 & 58 & 31 & 31 & 100 \\
\hline Sinop Üniversitesi & 52 & 52 & 100 & 52 & 7 & 13 & 21 & 4 & 19 & 21 & 4 & 19 & 21 & 21 & 100 \\
\hline $\begin{array}{l}\text { Süleyman Demirel } \\
\text { Üniversitesi }\end{array}$ & 41 & 40 & 98 & 41 & 41 & 100 & 41 & 41 & 100 & 41 & 41 & 100 & 41 & 41 & 100 \\
\hline Trakya Üniversitesi & 57 & 56 & 98 & 57 & 57 & 100 & 57 & 23 & 40 & 31 & 23 & 74 & 31 & 31 & 100 \\
\hline
\end{tabular}




\begin{tabular}{|l|c|c|c|c|c|c|c|c|c|c|c|c|c|c|c|} 
Uludağ Üniversitesi & 52 & 50 & $\mathbf{9 6}$ & 52 & 50 & $\mathbf{9 6}$ & 52 & 52 & $\mathbf{1 0 0}$ & 52 & 52 & $\mathbf{1 0 0}$ & 52 & 52 & $\mathbf{1 0 0}$ \\
\hline Uşak Üniversitesi & 47 & 47 & $\mathbf{1 0 0}$ & 47 & 28 & $\mathbf{6 0}$ & 47 & 7 & $\mathbf{1 5}$ & 31 & 13 & $\mathbf{4 2}$ & 21 & 21 & $\mathbf{1 0 0}$ \\
\hline Yıldız Teknik Üniversitesi & 47 & 46 & $\mathbf{9 8}$ & 47 & 47 & $\mathbf{1 0 0}$ & 62 & 62 & $\mathbf{1 0 0}$ & 62 & 61 & $\mathbf{9 8}$ & 62 & 62 & $\mathbf{1 0 0}$ \\
\hline Yüzüncü Yıl Üniversitesi & 41 & 41 & $\mathbf{1 0 0}$ & 41 & 41 & $\mathbf{1 0 0}$ & 41 & 23 & $\mathbf{5 6}$ & 31 & 31 & $\mathbf{1 0 0}$ & 31 & 31 & $\mathbf{1 0 0}$ \\
\hline $\begin{array}{l}\text { GENEL TOPLAM ve } \\
\text { GENEL ORTALAMA }\end{array}$ & $\mathbf{4 4 0 9}$ & $\mathbf{4 3 7 9}$ & $\mathbf{9 9}$ & $\mathbf{4 4 0 9}$ & $\mathbf{3 0 8 0}$ & $\mathbf{7 2}$ & $\mathbf{3 3 5 0}$ & $\mathbf{1 9 7 6}$ & $\mathbf{5 4}$ & $\mathbf{2 6 2 2}$ & $\mathbf{2 2 4 0}$ & $\mathbf{7 9}$ & $\mathbf{2 5 8 1}$ & $\mathbf{2 5 8 1}$ & $\mathbf{1 0 0}$ \\
\hline
\end{tabular}

Tablo 1'de Türkiye'de bulunan 68 devlet üniversitesinin Eğitim Fakülteleri'nde bulunan Fen Bilgisi Öğretmenliği programının genel kontenjan sayıları ile öğrenci yerleştirme sayıları; YKS ilk yerleştirme ve ek yerleştirme sonrasında kayıt yaptıranların sayılarının toplam sonuçları olarak düzenlenerek gösterilmiştir. Buna göre ilgili programının genel kontenjan sayıları YÖK tarafindan 2016 ve 2017 yıllarında 4409 olarak belirlenirken, 2018 yılında bu sayı yaklaşık \% 24 oranında azaltılarak 3350'ye; 2019 yllında ise bir önceki y1la göre yine yaklaşı \%.22 azaltılarak 2622’ye; 2020 y1lında ise 2581'e düşürülmüştür. Kontenjan sayıları her y1 ÖSYM ve YÖK tarafindan oluşturulan eğitim komisyonları tarafindan değerlendirilerek belirlenmektedir. Son 5 yıl içerisindeki ilgili ana bilim dalının kontenjan sayısının azaltılmasında, öğrencilerin YKS sonuçlanna göre yerleştirilme yüzdesinin, ortalamalarının etkili olduğu düşünülmektedir. 2016 yllında genel kontenjan oranına göre öğrencilerin \%99’ı tarafindan tercih edilmesinden dolayı 2017 yllında da genel kontenjan sayısında herhangi bir değişiklik yapılmamıştır. Ancak 2017 yılında ilgili program 3080 ögrenci tarafından tercih edilerek genel kontenjan sayısına göre yerleştirme oranında bir önceki yıla göre düşüş olarak \%72 seviyesine gerilemiştir. 2018 yllında 3350'ye düşürülen programa ek yerleştirmeler ve kayıtlar sonunda 1976 öğrencinin yerleştiği ve \% 54 dolaylarında doluluk oranının sağlandığ1 görülmektedir. Neredeyse yarıya yakın bir oranda genel kontenjanlardaki boşluk nedeniyle bir sonraki yılda kontenjan saylları azaltıldığ1 görülmektedir. 2019 y1lında 2622’ye düşürülen genel kontenjana \%79 doluluk oranı ile 2240 öğrenci yerleşmiştir. Son olarak 2020 yllında bir önceki yllın doluluk oranlarına göre 2581 olarak belirlenen genel kontenjana yeniden talepler artarak \%100 oranına ulaşıldığı görülmektedir.

Son 5 ylldaki veriler detaylı olarak incelendiğinde Balıkesir Üniversitesi (52), Boğaziçi Üniversitesi (52), Ege Üniversitesi (52), Osmangazi Üniversitesi (52), Harran Üniversitesi (41), Marmara Üniversitesi (52), Orta Doğu Teknik Üniversitesi (41), Süleyman Demirel Üniversitesi (41) ve Uludağ Üniversitesi (52) son 5 yıl içinde Fen Bilgisi öğretmenliği programında kontenjanının nerdeyse $\% 100$ doluluk oranını doldurması nedeniyle herhangi bir kontenjan azaltılması yapılmamıștır. Doluluk oranının her yıl \%100'e ulaştığı diğer bazı üniversitelerde Türkiye geneli genel ortalamanın düşük olduğu yıllar dikkate alınarak kontenjanların düşürüldüğü anlaşılmaktadır. Son 5 yll içerisindeki kontenjanlar1; Antalya Üniversitesi ile Necmettin Erbakan Üniversitesi 82'den 52'ye, Çukurova Üniversitesi ile Kocaeli Üniversitesi'nde 62'den 52'ye, Dokuz Eylül Üniversitesi 92'den 62'ye, Gazi Üniversitesi ile Hacettepe Üniversitesi 93'ten 52'ye, Erciyes Üniversitesi 72'den 52'ye ve Mersin Üniversitesi 52'den 41'e düşürülmüştür. Yine doluluk oranının her yıl \%100’e ulaşttğ1 sadece iki üniversitede kontenjan sayısının artırıldığ1 görülmüştür. Buna göre kontenjan sayıs1 İstanbul Üniversitesi'nde 57'den 62'ye, Y1ldı Teknik Üniversitesi'nde ise 47'den 62'ye yükseltilmiştir.

2016 yllında Fen Bilgisi öğretmenliği programı bulunan üniversitelerin neredeyse tamamı tam kontenjan doluluk oranına sahip iken ilerleyen yıllarda öğrenciler tarafindan tercih edilme ve YKS yerleştirilme sonuçlarına göre doluluk oranlarında düşüş yaşanması sonucunda bazı üniversitelerde \% $\% 50$ 'lik doluluk oranınına bile ulaşamadıkları ve bunun bir sonucu olarak da kontenjanların azaltıldığı düşünülmektedir. Azaltılan kontenjanlara rağmen öğrenci yerleştirme oranı düşük olan Ağrn İbrahim Çeçen Üniversitesi'nde 2018 yllından, Artvin Çoruh Üniversitesi'nde ve Bayburt Üniversitesi'nde ise 2019 yilından beri öğrenci alımının durdurulduğu anlaşılmaktadır.

Sonuç olarak 5 ylllık süreçte ülkemizdeki devlet üniversitelerinin Eğitim Fakülteleri'nde bulunan Fen Bilgisi öğretmenliği programının bulunduğu üniversite sayısı 68'den $65^{\prime}$ e düşürülürken; genel kontenjan sayısının ise 4409'dan 2581'e düşürülerek \%41 oranında azaltıldığı tespit edilmiştir.

2- 2016-2020 y1lları arasında Eğitim Fakülteleri’nde Biyoloji Öğretmenliği programı bulunan üniversiteler, kontenjan sayıları ile YKS ilk tercih ve ek yerleştirme sonuçlarına göre kayıt yaptıran öğrenci sayılarının düzenlendiği son 5 ylla ait veriler Tablo 2'de gösterilmiştir (ÖSYM, 2016; 2017b, c; 2018b, c; 2019b, c; 2020b, c). 
Tablo 2: Biyoloji Öğretmenliği programı bulunan Türkiye'deki üniversitelerin 2016-2020 ylllarına ait kontenjanları ve yerleșen öğrencilere ait içerik analizi

\begin{tabular}{|c|c|c|c|c|c|c|c|c|c|c|c|c|c|c|c|}
\hline \multirow[b]{2}{*}{ ÜNİVERSİTE } & \multicolumn{3}{|c|}{2016} & \multicolumn{3}{|c|}{2017} & \multicolumn{3}{|c|}{2018} & \multicolumn{3}{|c|}{2019} & \multicolumn{3}{|c|}{2020} \\
\hline & 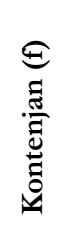 & 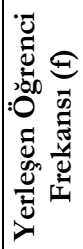 & 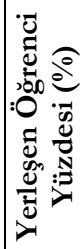 & 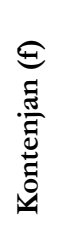 & 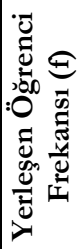 & 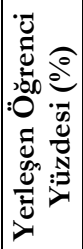 & 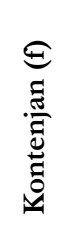 & 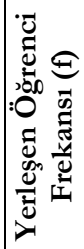 & 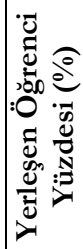 & 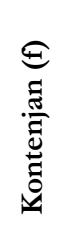 & 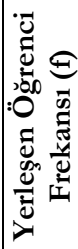 & 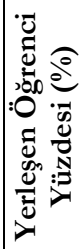 & 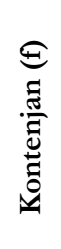 & 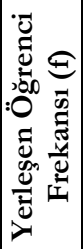 & 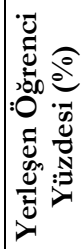 \\
\hline Atatürk Üniversitesi & 21 & 21 & 100 & 21 & 2 & 10 & 21 & 2 & 10 & 21 & 3 & 14 & - & - & - \\
\hline Balıkesir Üniversitesi & 21 & 21 & 100 & 21 & 21 & 100 & 21 & 13 & 62 & 21 & 20 & 95 & 21 & 21 & 100 \\
\hline Dicle Üniversitesi & 21 & 21 & 100 & 21 & 19 & 90 & 21 & 3 & 14 & - & - & - & - & - & - \\
\hline Dokuz Eylül Üniversitesi & 21 & 21 & 100 & 21 & 21 & 100 & 21 & 21 & 100 & 21 & 21 & 100 & 21 & 21 & 100 \\
\hline Gazi Üniversitesi & 21 & 21 & 100 & 21 & 21 & 100 & 21 & 21 & 100 & 21 & 21 & 100 & 21 & 21 & 100 \\
\hline Hacettepe Üniversitesi & 21 & 21 & 100 & 21 & 21 & 100 & 21 & 21 & 100 & 21 & 21 & 100 & 21 & 21 & 100 \\
\hline $\begin{array}{l}\text { Karadeniz Teknik-Trabzon } \\
\text { Üniversitesi } \\
\end{array}$ & 21 & 21 & 100 & 21 & 21 & 100 & 21 & 5 & 24 & 21 & 1 & 5 & - & - & - \\
\hline Marmara Üniversitesi & 21 & 21 & 100 & 21 & 21 & 100 & 21 & 20 & 95 & 21 & 21 & 100 & 21 & 21 & 100 \\
\hline $\begin{array}{l}\text { Necmettin Erbakan } \\
\text { Üniversitesi }\end{array}$ & 21 & 21 & 100 & 21 & 21 & 100 & 21 & 6 & 29 & 21 & 13 & 62 & 21 & 21 & 100 \\
\hline Ondokuz Mayıs Üniversitesi & 21 & 21 & 100 & 21 & 19 & 90 & 21 & 11 & 52 & 21 & 14 & 67 & 21 & 21 & 100 \\
\hline Yüzüncü Y1l Üniversitesi & 21 & 21 & 100 & 21 & 7 & 33 & 21 & 1 & 5 & - & - & - & - & - & - \\
\hline $\begin{array}{l}\text { GENEL TOPLAM ve } \\
\text { GENEL ORTALAMA }\end{array}$ & 231 & 231 & 100 & 231 & 194 & 84 & 231 & 124 & 54 & 189 & 135 & 71 & 147 & 147 & 100 \\
\hline
\end{tabular}

Tablo 2'de Türkiye'deki Eğitim Fakülteleri'nin 11'inde bulunan Biyoloji öğretmenliği programının genel kontenjan sayıları ile öğrenci yerleştirme sayıları; YKS ilk yerleştirme ve ek yerleştirme sonrasında kayıt yaptıranların sayılarının toplam sonuçları olarak düzenlenerek gösterilmiştir. Buna göre ilgili programinin genel kontenjan sayıları YÖK tarafindan 2016, 2017 ve 2018 yıllarında yil bazında 231 olarak belirlenirken, 2019 yllında bu say1 \%18 azaltılarak 189'a, 2020 yılında ise bir önceki yıla göre yine aynı oranda azaltılarak 147'ye düşürülmüştür. Kontenjan sayıları ile öğrencilerin yerleştirilme yüzdeleri incelendiğinde 2016 yılında \%100 doluluk oranına sahip olan ilgili program 2017 yllında genel yerleştirme yüzdesi ortalaması olarak \%84' e gerilemiştir. 2018 yllinda ise genel kontenjan sayılarının neredeyse yarıs boş kalmıştır ve \%54 oranında öğrencilerin ilgili programa yerleştirildiği görülmüştür. 2019 yllında 189 olarak belirlenen kontenjanlara \%71 oranında; 2020 yllinda ise 147 olan kontenjanlara \%100 oranında öğrenci yerleşmiştir. Kontenjan sayıları 2014 yllı itibari ile ilgili programın bulunduğu tüm üniversitelerde 21 olarak sabitlenmiştir. Yillara göre genel kontenjan sayılarındaki azalmanın sebebi olarak bir önceki yıla göre doluluk oranının düşük olduğu üniversitelerde o yıl için kontenjan sayısının sıfır olarak belirlenmesinden kaynaklandığı, üniversitelerin genel kontenjan sayılarında değişiklik yapılmadı̆̆1 görülmektedir.

Yıllara göre üniversitelerin doluluk oranları incelendiğinde Dokuz Eylül Üniversitesi’ne, Gazi Üniversitesi'ne, Hacettepe Üniversitesi'ne son 5 yllda \%100 doluluk oranında öğrenci yerleştirilmiştir. Yine Marmara Üniversitesi'nde de bu oran \%100 oranında olup sadece 2018 yllında $\% 95$ düzeyinde olmuştur. Balıkesir Üniversitesi, Necmettin Erbakan Üniversitesi ve Ondokuz Mayıs Üniversiteleri ise 2016 ve 2017 yıllarında tam doluluk kapasitesine ulaşmış olsa da 2018 ve 2019 yıllarında öğrenci yerleştirilme yüzdesinde düşüş yaşamıştır ancak 2020 yılı itibariyle yeniden tam doluluk oranına ulaşmıştır. Dicle Üniversitesi ve Yüzüncü Yıl Üniversitelerinde bulunan ilgili programa 2017 ve 2018 yıllarında çok düşük sayıda öğrenci yerleştirilmesinden dolayı 2019 yllı itibariyle öğrenci alımı durdurulmuştur. Yine benzer bir durum Atatürk Üniversitesi ve Trabzon Üniversitelerinde de görülmüş olup bu üniversitelerdeki yerleştirme oranlarının çok düşük olması nedeniyle de 2020 yllından itibaren öğrenci alımı durdurulmuştur.

Sonuç olarak 5 yıllık süreçte ülkemizdeki devlet üniversitelerinin Eğitim Fakülteleri’nde bulunan Biyoloji öğretmenliği programının bulunduğu üniversite sayısı 11den 7’e düşürülürken; genel kontenjan sayısının ise 231'den 147'ye düşürülerek \%36 oranında azaltıldığı sonucuna ulaşılmıştır. 
3- 2016-2020 yılları arasında Eğitim Fakülteleri’nde Fizik Öğretmenliği programı bulunan üniversiteler, kontenjan sayıları ile YKS ilk tercih ve ek yerleştirme sonuçlarına göre kayıt yaptıran öğrenci sayılarının düzenlendiği son 5 ylla ait veriler Tablo 3’te gösterilmiştir (ÖSYM, 2016; 2017 b,c; 2018 b,c; 2019 b,c; 2020 b,c).

Tablo 3: Fizik Öğretmenliği programı bulunan Türkiye'deki üniversitelerin 2016-2020 yıllarına ait kontenjanları ve yerlesen öğrencilere ait içerik analizi

\begin{tabular}{|c|c|c|c|c|c|c|c|c|c|c|c|c|c|c|c|}
\hline \multirow[b]{2}{*}{ ÜNİVERSİTE } & \multicolumn{3}{|c|}{2016} & \multicolumn{3}{|c|}{2017} & \multicolumn{3}{|c|}{2018} & \multicolumn{3}{|c|}{2019} & \multicolumn{3}{|c|}{2020} \\
\hline & 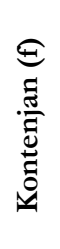 & 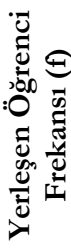 & 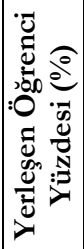 & 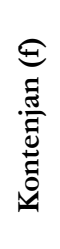 & 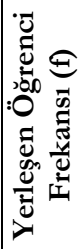 & 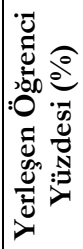 & 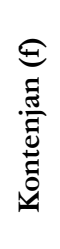 & 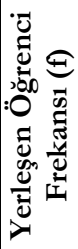 & 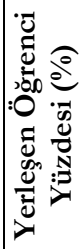 & 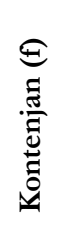 & 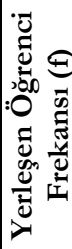 & 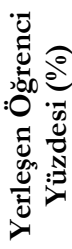 & 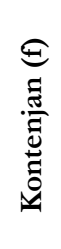 & 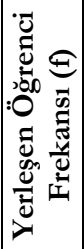 & 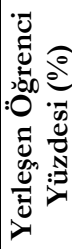 \\
\hline Balıkesir Üniversitesi & 21 & 20 & 95 & 21 & 10 & 48 & 21 & 1 & 5 & - & - & - & - & - & - \\
\hline Boğaziçi Üniversitesi & 21 & 20 & 95 & 21 & 21 & 100 & 21 & 20 & 95 & 21 & 21 & 100 & 21 & 21 & 100 \\
\hline Dicle Üniversitesi & - & - & - & 21 & 1 & 5 & 21 & 2 & 10 & - & - & - & - & - & - \\
\hline Dokuz Eylül Üniversitesi & 21 & 21 & 100 & 21 & 21 & 100 & 21 & 21 & 100 & 21 & 21 & 100 & 21 & 21 & 100 \\
\hline Gazi Üniversitesi & 21 & 20 & 95 & 21 & 21 & 100 & 21 & 21 & 100 & 21 & 21 & 100 & 21 & 21 & 100 \\
\hline Hacettepe Üniversitesi & 21 & 21 & 100 & 21 & 21 & 100 & 21 & 21 & 100 & 21 & 21 & 100 & 21 & 21 & 100 \\
\hline Marmara Üniversitesi & 21 & 21 & 100 & 21 & 21 & 100 & 21 & 21 & 100 & 21 & 21 & 100 & 21 & 21 & 100 \\
\hline $\begin{array}{l}\text { Necmettin Erbakan } \\
\text { Üniversitesi }\end{array}$ & 21 & 21 & 100 & 21 & 11 & 52 & 21 & 2 & 10 & 21 & 5 & 24 & 21 & 21 & 100 \\
\hline Ondokuz Mayis Üniversitesi & - & - & - & - & - & - & - & - & - & 21 & 5 & 24 & 21 & 21 & 100 \\
\hline $\begin{array}{l}\text { Orta Doğu Teknik } \\
\text { Üniversitesi }\end{array}$ & 21 & 21 & 100 & 21 & 21 & 100 & 21 & 21 & 100 & 21 & 21 & 100 & 21 & 21 & 100 \\
\hline $\begin{array}{l}\text { GENEL TOPLAM ve } \\
\text { GENEL ORTALAMA }\end{array}$ & 168 & 165 & 98 & 189 & 148 & 78 & 189 & 130 & 69 & 168 & 136 & 81 & 168 & 168 & 100 \\
\hline
\end{tabular}

Tablo 3'te Türkiye'deki Eğitim Fakülteleri'nin 10'unda bulunan Fizik öğretmenliği programının genel kontenjan sayıları ile öğrenci yerleştirme sayıları; YKS ilk yerleştirme ve ek yerleştirme sonrasında kayıt yaptıranların nihai sonuçları düzenlenerek gösterilmiştir. Buna göre ilgili programının genel kontenjan saylları 2016 yllında YÖK tarafindan 8 üniversitede toplam 168 olarak belirlenmiştir. 2016 yllında genel doluluk oranının \%98 düzeyinde olmasından dolayı 2017 ve 2018 yllarında ilgili program bulunan bir üniversitede (Dicle Üniversitesi) daha öğrenci alımının kabul edilerek toplam kontenjan sayısının 189'e çıkarıldığı görülmektedir. Ancak 2017 yilında genel doluluk ortalamasının \%78'e; 2018'de de \%69'a düssmesinden dolayı 2019 ve 2020 yıllarından kontenjanın yeniden 168'e düşürüldüğü görülmektedir. Kontenjan saylarının belirlenmesinde ÖSYM ve YÖK tarafindan belirlenen eğitim komisyonunca yine 2014 y1lından sonra ilgili programın bulunduğu tüm üniversitelerde kontenjanın y1llık 21 olarak sabitlendiği ancak yıllara göre öğrenci alımının yapıldığı üniversitelerin önceki yıllardaki doluluk oranlarının dikkate alınarak belirlendiği düșünülmektedir.

Üniversitelerin yllara göre doluluk oranları incelendiğinde; Dokuz Eylül Üniversitesi'ne, Hacettepe Üniversitesi’ne, Marmara Üniversitesi'nde ve Orta Doğu Teknik Üniversitesi'ne son 5 yllda \%100 doluluk oranında öğrenci yerleştirildiği; yine doluluk oranının Gazi Üniversitesi’nde ve Boğaziçi Üniversitesi’nde de $\% 100$ oranında olduğu ancak bir kaç yılda \%95 düzeyinde olduğu görülmektedir. Programın bulunduğu diğer üniversitelerdeki öğrencilerin yerleştirilme oranları incelendiğinde ise son 5 yılllk sürede çeşitli dalgalanmaların olduğu anlaşılmaktadır. Buna göre son 5 yıllık süre içerisinde her yıl öğrenci alımına devam edilen Necmettin Erbakan Üniversitesi'nde 2016 yilında \%100 doluluk seviyesinde olan programa, 2017 yylında \%52 oranında, 2018 yilında \%10 oranında, 2019 yılında \%24 oranında öğrenci yerleștirilirken son 3 yıldaki düşüşe rağmen 2020 yllında $\% 100$ doluluk oranına yeniden ulaştığı görülmektedir. Dicle Üniversitesi incelendiğinde 2016 yllında kontenjan sayısı bulunmayan üniversiteye 2016 yllındaki ilgili programa \%98 ortalamada öğrenci yerleştirilmesinden kaynaklandığ düşünülerek 2017 ve 2018 ylllarında 21 kişilik kontenjan verilmiştir. Ancak her iki yllda da oldukça düşük bir oranda öğrenci yerleştirilen 
üniversiteye 2019 ve 2020 yıllarında yeniden öğrenci alımı durdurulmuştur. Benzer bir şekilde Balıkesir Üniversitesi'nde de 2016 yllında öğrenci yerleştirilmesinde $\% 95$ doluluk oranına sahip olan üniversitenin 2018 yılındaki doluluk oranının \%48’e 2018 yllında ise \%5 seviyelerine kadar düşmesinden dolayı 2019 ve 2020 yıllarında ilgili programa herhangi bir kontenjanın verilmediği anlaşılmaktadır. Kontenjan sayılarındaki azalmaya bağlı olarak öğrenci alımı durdurulan üniversitelerin aksine Ondokuz Mayıs Üniversitesi'nde tersi bir durumun olduğu tespit edilmiştir. 2019 yllına kadar herhangi bir kontenjanı bulunmayan programa 2019 yilında 21 kişilik kontenjan verilmiştir ve \%24 oranında öğrenci yerleştirilmiştir. Düşük orana sahip olmasına rağmen ve 2020 yllında yeniden aynı kontenjan verilen üniversiteye \%100 doluluk oranında öğrencinin yerleştirildiği görülmektedir.

Sonuç olarak 5 yillık süreçte ülkemizdeki devlet üniversitelerinin Eğitim Fakülteleri'nde bulunan Fizik öğretmenliği programının bulunduğu üniversite sayısında yıllara göre değişikliklerin olduğu; 2017 ve 2018 yıllarında 9 üniversitede; 2016, 2019 ve 2020 yıllarında 8 üniversitede öğrenci yerleştirildiği; genel kontenjan sayısının ise 168 olarak belirlendiği sonucuna ulaşılmıştır.

4- 2016-2020 yılları arasında Eğitim Fakülteleri'nde Kimya Öğretmenliği programı bulunan üniversiteler, kontenjan sayıları ile YKS ilk tercih ve ek yerleştirme sonuçlarına göre kayıt yaptıran öğrenci sayılarının düzenlendiği son 5 yıla ait veriler Tablo 4'te gösterilmiştir (ÖSYM, 2016; 2017 b,c; 2018 b,c; 2019 b,c; 2020 b,c).

Tablo 4: Kimya Öğretmenliği programı bulunan Türkiye’deki üniversitelerin 2016-2020 y1llarına ait kontenjanları ve yerleşen öğrencilere ait içerik analizi

\begin{tabular}{|c|c|c|c|c|c|c|c|c|c|c|c|c|c|c|c|}
\hline \multirow[b]{2}{*}{ ÜNİVERSİTE } & \multicolumn{3}{|c|}{2016} & \multicolumn{3}{|c|}{2017} & \multicolumn{3}{|c|}{2018} & \multicolumn{3}{|c|}{2019} & \multicolumn{3}{|c|}{2020} \\
\hline & 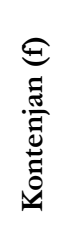 & 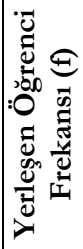 & 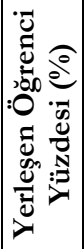 & 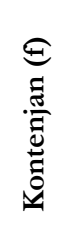 & 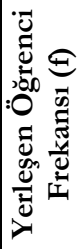 & 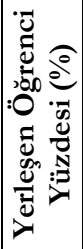 & 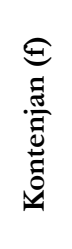 & 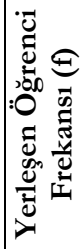 & 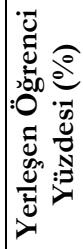 & 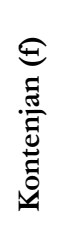 & 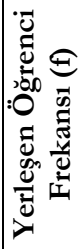 & 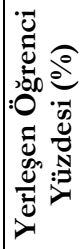 & 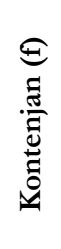 & 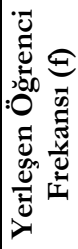 & 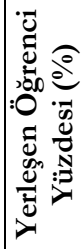 \\
\hline Atatürk Üniversitesi & 21 & 21 & 100 & 21 & 5 & 24 & 21 & 0 & 0 & 21 & 1 & 5 & - & - & - \\
\hline Balıkesir Üniversitesi & 21 & 21 & 100 & 21 & 11 & 52 & 21 & 4 & 19 & 21 & 9 & 43 & 21 & 21 & 100 \\
\hline Boğaziçi Üniversitesi & 21 & 20 & 95 & 21 & 21 & 100 & 21 & 21 & 100 & 21 & 21 & 100 & 21 & 21 & 100 \\
\hline $\begin{array}{l}\text { Çanakkale Onsekiz Mart } \\
\text { Üniversitesi }\end{array}$ & 21 & 21 & 100 & 21 & 21 & 100 & 21 & 9 & 43 & 21 & 10 & 48 & 21 & 21 & 100 \\
\hline Dicle Üniversitesi & 21 & 21 & 100 & 21 & 8 & 38 & 21 & 5 & 24 & - & - & - & - & - & - \\
\hline Dokuz Eylül Üniversitesi & 21 & 20 & 95 & 21 & 20 & 95 & 21 & 21 & 100 & 21 & 21 & 100 & 21 & 21 & 100 \\
\hline Gazi Üniversitesi & 21 & 19 & 90 & 21 & 21 & 100 & 21 & 21 & 100 & 21 & 21 & 100 & 21 & 21 & 100 \\
\hline Hacettepe Üniversitesi & 21 & 16 & 76 & 21 & 21 & 100 & 21 & 21 & 100 & 21 & 21 & 100 & 21 & 21 & 100 \\
\hline Marmara Üniversitesi & 21 & 21 & 100 & 21 & 21 & 100 & 21 & 21 & 100 & 21 & 20 & 95 & 21 & 21 & 100 \\
\hline $\begin{array}{l}\text { Necmettin Erbakan } \\
\text { Üniversitesi }\end{array}$ & 21 & 21 & 100 & 21 & 11 & 52 & 21 & 3 & 14 & 21 & 5 & 24 & 21 & 21 & 100 \\
\hline $\begin{array}{l}\text { Orta Doğu Teknik } \\
\text { Üniversitesi }\end{array}$ & 21 & 19 & 90 & 21 & 21 & 100 & 21 & 21 & 100 & 21 & 21 & 100 & 21 & 20 & 95 \\
\hline $\begin{array}{l}\text { Karadeniz Teknik Trabzon } \\
\text { Üniversitesi }\end{array}$ & 21 & 21 & 100 & 21 & 12 & 57 & 21 & 1 & 5 & - & - & - & - & - & - \\
\hline Yüzüncü Y1l Üniversitesi & 21 & 21 & 100 & 21 & 4 & 19 & 21 & 3 & 14 & 21 & 3 & 14 & - & - & - \\
\hline GENEL TOPLAM & 273 & 262 & 96 & 273 & 197 & 72 & 273 & 151 & 55 & 231 & 153 & 66 & 189 & 188 & 99 \\
\hline
\end{tabular}

Tablo 4’te Türkiye'deki Eğitim Fakülteleri'nin 13'ünde bulunan Kimya öğretmenliği programinın genel kontenjan sayıları ile öğrenci yerleştirme sayıları; YKS ilk yerleştirme ve ek yerleştirme sonrasında kayıt yaptıranların nihai sonuçları düzenlenerek gösterilmiştir. Buna göre ilgili programının genel kontenjan sayıları incelendiğinde YÖK tarafindan 2016, 2017 ve 2018 yıllarında 273 olarak belirlenmiştir. 2016 y1lında öğrenci yerleştirilme genel ortalaması olarak \%96 olarak hesaplanan programda 2017 y1lında da aynı kontenjan sayılarının belirlenmiş olması daha önce incelenen diğer fen bilgisi öğretmenliği programı ile benzerlik göstermektedir. Ancak 2017 sonuçlarına göre \%72 oranında doluluk oranı seviyelerine gerileyen 
programda 2018 yllında diğer programlardaki gibi herhangi bir kontenjan azaltılması yapılmamıştır. Ancak 2018 yllının sonuçlarına göre \%55 seviyelerinde genel doluluk ortalamasına sahip programın 2019 yllı kontenjanları belirlenirken bir üniversitede durdurulma kararına istinaden genel kontenjan sayısının 231'e düşürüldüğü görülmektedir. 2019 yılında öğrencilerin yerleştirme sonuçları sonrasında genel olarak \%66 doluluk oranına gerileyen programda bir üniversitenin daha öğrenci alımının durdurularak genel kontenjan sayısı 2020 yılında 189 olarak belirlenmiştir. Kontenjan sayılarının belirlenmesinde yine 2014 yllından sonra ilgili programın bulunduğu üniversitelerde 21 olarak sabitlendiği ancak yllara göre öğrenci alımının yapıldığı üniversitelerin bir önceki yıldaki doluluk oranlarının etkili olduğu anlaşılmaktadır. Düşük oranlarda olan veya hiç dolmayan üniversitelerin kontenjanları sıfır olarak belirlenmiştir.

Üniversitelerin yıllara göre doluluk oranları incelendiğinde; ilgili program bulunan üniversitelerde son beş yilın her yilında \%100 doluluk oranına ulaşan bir üniversite olmadığı ancak genel olarak ortalamada \%100 doluluk oranına yakın olanların Boğaziçi Üniversitesi, Dokuz Eylül Üniversitesi, Gazi Üniversitesi, Marmara Üniversitesi ve Orta Doğu Teknik Üniversitesi olduğu anlaşılmaktadır. Hacettepe Üniversitesi'ne ise sadece 2016 yllinda \%76 doluluk oranında ancak diğer yıllarda tam doluluk oranında öğrencinin yerleştiği görülmektedir. Çanakkale Onsekiz Mart Üniversitesi’nin son 5 yıldaki doluluk oranı incelendiğinde 2016 ve 2017 'de tam doluluk oranına sahipken 2018 ve 2019 'da \%50'nin altında olduğu ancak 2020 yılında yeniden \%100 doluluk oranına ulaştığı anlaşılmaktadır. Balıkesir Üniversitesi ve Necmettin Erbakan Üniversiteleri'nde ise 2016 yllında \%100 doluluk oranında iken 2017'de yaklaşık yarıya yakın doluluk oranında olduğu, 2018 ve 2019 yıllarında düşük oranda doluluk olduğu ancak 2020 y1lında yeniden kontenjanın tamamının dolduğu anlaşılmaktadır. Atatürk Üniversitesi’nin ve Yüzüncü Yıl Üniversitesi'nin son 5 yl içerisinde doluluk oranları incelendiğinde 2016 yllinda $\% 100$ doluluk oranına sahipken 2017, 2018 ve 2019 yıllarında doluluk oranının \%20’ lerin altına düşmesinden dolayı 2020 yılı itibari ile kontenjan sayısının sıfirlandığı; yine benzer şekilde Dicle Üniversitesi'ninde ve Trabzon Üniversitesi’nde 2017 yll sonrasında düşük oranlarda öğrenci yerleştirildiği için 2019 ve 2020 ylllarında öğrenci alımının yapılmadığı belirlenmiştir. Sonuç olarak 5 yıllık süreçte ülkemizdeki devlet üniversitelerinin Eğitim Fakülteleri’nde bulunan Kimya öğretmenliği programının bulunduğu üniversite sayıs1 13'ten 9'a düşürülürken, genel kontenjan sayısının ise \%30 oranında azaldığ1 ve 273'ten 189'a düşürüldüğ̈ sonucuna ulaşılmıştır.

5- 2016-2020 yılları arasında fen bilimleri branş bazındaki genel karşılaştırma yapılmış olup Tablo 5’te gösterilmiştir (ÖSYM, 2016; 2017 b,c; 2018 b,c; 2019 b,c; 2020 b,c).

Tablo 5: 2016-2020 yıllarına ait Fen Bilimleri Öğretmenliklerinin kontenjan sayılarının, yerleşen öğrenci sayılarının ve yüzdelerinin karşılaştırılması

\begin{tabular}{|c|c|c|c|c|c|}
\hline \multicolumn{2}{|c|}{ Yıl/Branş Bazında Sayısal Veriler } & $\begin{array}{l}\text { Fen Bilgisi } \\
\text { Öğretmenliği }\end{array}$ & $\begin{array}{c}\text { Biyoloji } \\
\text { Öğrretmenliği }\end{array}$ & $\begin{array}{c}\text { Fizik } \\
\text { Öğgretmenliği }\end{array}$ & $\begin{array}{c}\text { Kimya } \\
\text { Öğrretmenliği }\end{array}$ \\
\hline \multirow{3}{*}{2016} & Kontenjan Sayıs1 (f) & 4409 & 231 & 168 & 273 \\
\hline & Yerleşen Öğrenci Sayısı (f) & 4379 & 231 & 165 & 262 \\
\hline & Yerleşen Öğrenci Yüzdesi(\%) & 99 & 100 & 98 & 96 \\
\hline \multirow{3}{*}{2017} & Kontenjan Sayısı (f) & 4409 & 231 & 189 & 273 \\
\hline & Yerleşen Öğrenci Sayısı (f) & 3080 & 194 & 148 & 197 \\
\hline & Yerleşen Öğrenci Yüzdesi(\%) & 72 & 84 & 78 & 72 \\
\hline \multirow{3}{*}{2018} & Kontenjan Sayısı (f) & 3350 & 231 & 189 & 273 \\
\hline & Yerleşen Öğrenci Sayısı (f) & 1976 & 124 & 130 & 151 \\
\hline & Yerleşen Öğrenci Yüzdesi(\%) & 54 & 54 & 69 & 55 \\
\hline \multirow{3}{*}{2019} & Kontenjan Sayısı (f) & 2622 & 189 & 168 & 231 \\
\hline & Yerleşen Öğrenci Sayısı (f) & 2240 & 135 & 136 & 153 \\
\hline & Yerleşen Öğrenci Yüzdesi(\%) & 79 & 71 & 81 & 66 \\
\hline \multirow{3}{*}{2020} & Kontenjan Sayısı (f) & 2581 & 147 & 168 & 189 \\
\hline & Yerleşen Öğrenci Sayısı (f) & 2581 & 147 & 168 & 188 \\
\hline & Yerleşen Öğrenci Yüzdesi(\%) & 100 & 100 & 100 & 99 \\
\hline
\end{tabular}

Tablo 5'e göre 2016 yılında fen bilimleri öğretmenliği programlarının toplam kontenjan sayısı Türkiye genelinde 5081 olarak belirlenirken; bu sayının yaklaşık \%86'sını 4409 kişi ile fen bilgisi öğretmenliği, \%5,3’ünü 273 kişi ile kimya öğretmenliği, 4,5’ini 231 kişi ile biyoloji öğretmenliği ve \%3,3’ünü 168 kişi 
kontenjan sayısı ile fizik öğretmenliği programı oluşturmaktadır. Genel kontenjan sayısına göre ilgili programlara 2016 YKS sonuçlarına göre toplam 5037 öğrenci yerleştirilmiştir. 2017 yllının verileri incelendiğinde fen bilimlerinin tüm branşlarında Türkiye geneli kontenjan sayısının 5102'ye çıktığını, bu sayının ise sadece fizik öğretmenliğinde 21 kişilik artıştan meydana geldiği görülmektedir. YKS sonuçlarına göre toplamda 3619 öğrencinin yerleştirildiği görülmektedir. 2018 yllında belirlenen genel kontenjan sayılarının biyoloji öğretmenliği, fizik öğretmenliği ve kimya öğretmenliği programlarında değişmediği ancak fen bilgisi öğretmenliği kontenjan sayısının 3350'ye düşürülmesinden dolayı Türkiye genelinde fen bilimleri öğretmenliği programları genel kontenjan sayısı 4043 olarak belirlenmiştir. 2018 YKS sonuçlarına göre bu kontenjanların neredeyse yarıya yakını boş kalarak toplamda 2381 öğrencinin yerleştirildiği anlaşılmaktadır. 2018 yılında tüm branşlarda yaşanan yerleştirme sayılarının düşüklüğü nedeniyle tüm branşların genel kontenjan sayıları azaltılmıştır. Buna göre 2019 yılında fen bilimleri öğretmenliği programlarının genel kontenjan saylları Türkiye geneli 3210 olarak belirlenmiştir. Bu sayının yaklaşık \%82'sine denk gelen 2622 kişi fen bilgisi öğretmenliği, \%7,2'sine denk gelen 153 kişi kimya öğretmenliği; \%5,9’una denk gelen 189 kişi biyoloji öğretmenliği ve \%5,2'sine denk gelen 168 kişi fizik öğretmenliği olarak belirlenmiştir. YKS sonuçlarına göre tüm branşlara genel toplamda 2664 öğrencinin yerleştirildiği ve yine kontenjan sayılarının \%20 dolaylarında boşta kaldığı anlaşılmaktadır. 2020 yılında kontenjan sayılarının bir önceki yılda yine boş kalmasının sonucu olarak fizik öğretmenliği hariç diğer branşların kontenjan sayılarında yeniden azalma olmuştur ve Türkiye geneli genel kontenjan sayısı 3085 olarak belirlenmiştir. 2020 YKS sonuçlarında genel kontenjan sayısında sadece 1 kişilik boş kontenjan kalmış olup 5 sene önceki gibi tüm branş bazında \%100 doluluk sağlanmıştır.

2016-2020 yılları içerisindeki 5 yıllık süreçteki fen bilimleri öğretmenliklerinin genel kontenjan sayılarına göre yerleştirilen öğrenci yüzdeleri her branş bazında ayrı ayrı grafiklerde de gösterilmiştir.

Grafik 1'de fen bilgisi öğretmenliğine ilişkin 2016-2020 yıllarında genel kontenjanlara göre ilgili programı tercih ederek yerleştirilen öğrenci yüzdelerinin karşılaştırması gösterilmiştir. Buna göre ilgili programa 2016 yllında \%99 oranında ögrenci yerleşmişken; 2017'de bu oran \%72'ye, 2018'de ise \%54'e kadar gerilemiştir. 2019 yllında yeniden \%79 seviyelerine ulaşan ilgili programın doluluk oranı 2020 yllı itibari ile yeniden 5 sene önceki doluluk oranına ulaşmış olup \%100 seviyesine çıkmıştır.

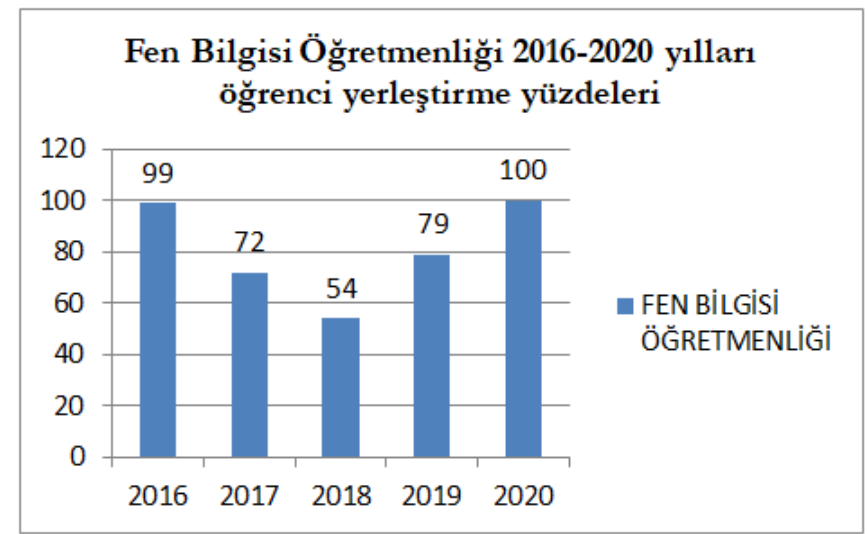

Grafik 1: 2016-2020 yıllarına ait Fen Bilgisi Öğretmenliği programına yerleșen öğrenci yüzdeleri

Grafik 2'de biyoloji öğretmenliğine ilişkin 2016-2020 yillarında genel kontenjanlara göre ilgili program1 tercih ederek yerleştirilen öğrenci yüzdelerinin karşılaştırması gösterilmiştir. Buna göre biyoloji öğretmenliği programına 2016 yllında \%100 oranında öğrenci yerleşmiştir. Ancak bu oran 2017'de \%84'e, 2018 'de ise nerdeyse yarıya yakını dolarak \%54'lere düşmüştür. 2019 yllinda yeniden artışa geçerek \%71 seviyelerine ulaşan ilgili programın doluluk oranı 2020 yllı itibari ile yeniden 5 sene önceki doluluk oranına ulaşmış olup $\% 100$ seviyesine çıkmıstır. 


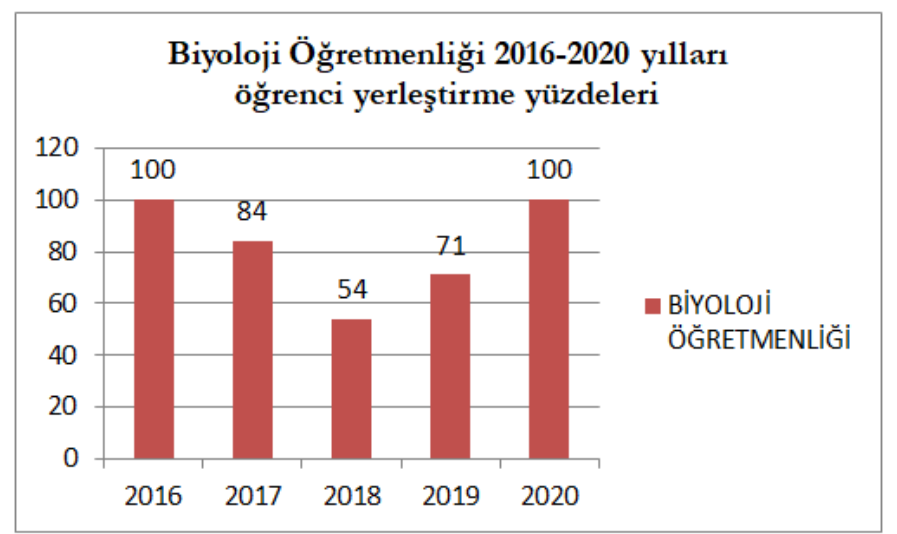

Grafik 2: 2016-2020 ylllarına ait Biyoloji Öğretmenliği programına yerleşen öğrenci yüzdeleri

Grafik 3’te fizik öğretmenliğine ilişkin 2016-2020 yıllarında genel kontenjanlara göre ilgili programı tercih ederek yerleştirilen öğrenci yüzdelerinin karşılaştırması gösterilmiştir. Buna göre ilgili programa 2016 yllında \%98 oranında öğrenci yerleşmişken; 2017'de bu oran \%78'e, 2018'de ise \%69e gerilemiştir. 2019 yllında yeniden artış göstererek \%81'e ulaşırken 2020 yllında bu artıs devam ederek \%100 doluluk seviyesine çıkmıştır.

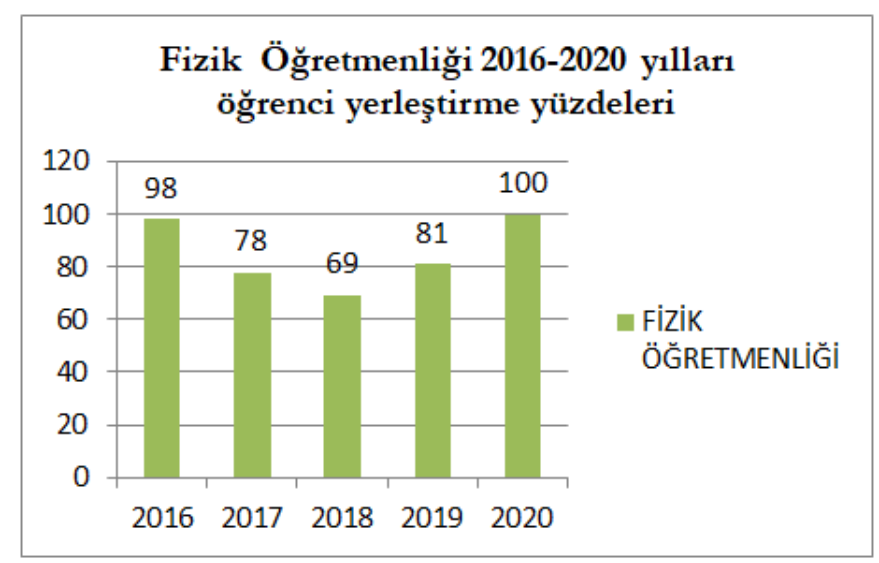

Grafik 3: 2016-2020 ylllarına ait Fizik Öğretmenliği programına yerleşen öğrenci yüzdeleri

Grafik 4'te kimya öğretmenliğine ilişkin 2016-2020 yllarında genel kontenjanlara göre ilgili programı tercih ederek yerleştirilen öğrenci yüzdelerinin karşılaştırması gösterilmiştir. Buna göre kimya öğretmenliği programına 2016 yllında \%96 oranında öğrenci yerleşmiştir. Diğer branşlarda görüldüğ̈ gibi kimya öğretmenliği yerleştirme oranlarında 2017 ve 2018 yllarında düşüş gözlemlenmiştir. 2017'de öğrenci yerleştirme oran1 \%72'ye, 2018'de ise \%55'e kadar gerilemiştir. 2019 yllında yeniden öğrenci yerleştirme yüzdesinde artış görülerek \%66 seviyelerine ulaşırken 2020 yllında bu artış devam ederek \%100 doluluk seviyesine ulaşmıştır. 


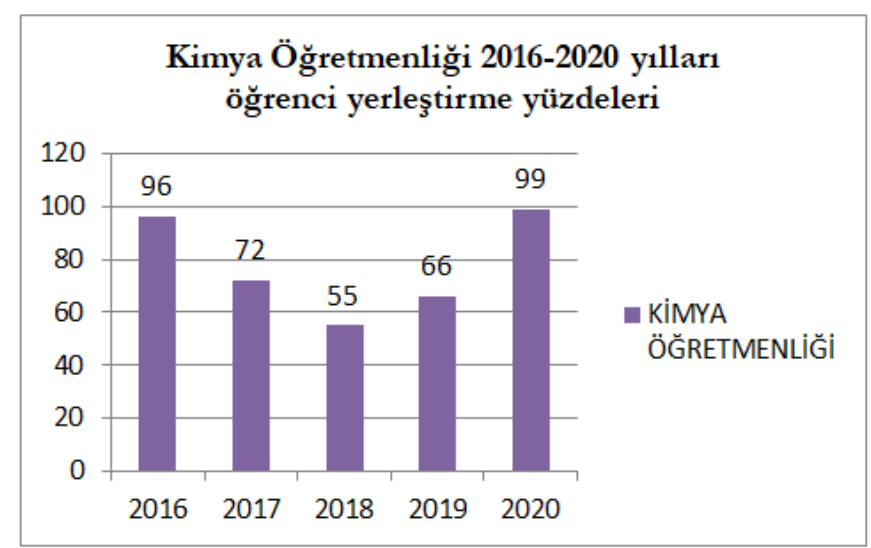

Grafik 4: 2016-2020 y1llarına ait Biyoloji Öğretmenliği programına yerleşen öğrenci yüzdeleri

Yıllara göre fen bilimleri öğretmenliklerinin genel kontenjan sayılarına ve YKS sonuçlarına göre öğrenci yerleştirme yüzdelerinin kıyaslandığı Grafik 5’te ise 2016 ve 2020 yıllarında fen bilgisi öğretmenliği, biyoloji öğretmenliği, fizik öğretmenliği ve kimya öğretmenliği programlarının tamamının birbirleri ile kıyaslandığ1 oranlar gösterilmiştir. Buna göre 5 sene öncesinde tüm branşlarda neredeyse $\% 100$ doluluk oranında öğrenci yerleştiği görülmektedir. 2017 yılında ise tüm branşların doluluk oranlarında \%20-30 dolaylarında azalma gözlenirken, 2018 yilında bu oranın daha da azalarak doluluk oranının \%50-60 seviyelerine gerilediği anlaşılmıştır. 2018 yllında fen bilimleri branşlarından biyoloji öğretmenliği programına, 2018 yllında ise fizik öğretmenliği programına yerleşen öğrenci yüzdesi diğer branşlara göre daha yüksek olduğu anlaşılmaktadır. 2019 yllnda ise bir önceki yıla göre öğrenci yerleştirme yüzdesinde artışı olduğu ve doluluk oranının yeniden \%70-80 seviyelerine ulaşıtı̆ı görülmektedir. Ancak kimya öğretmenliğinde bu oranın diğer branşlara göre daha geride kaldığı görülmektedir. 2020 yllında tüm fen bilimleri ögretmenliklerinde yeniden öğrenci yerleştirme oranlarının \%100’e ulaştığı sonucuna ulaşılmıştır.

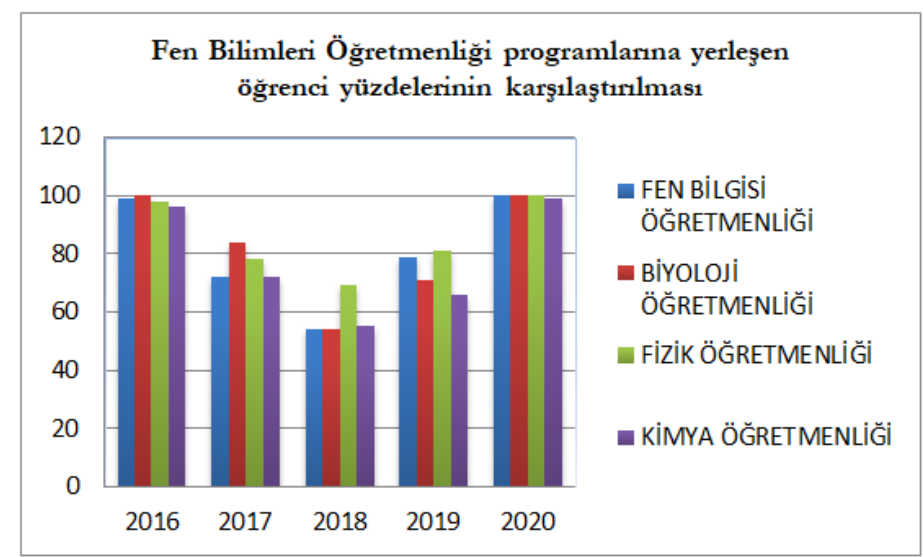

Grafik 5: Fen Bilimleri Öğretmenliği programlarına 2016-2020 yıllarında yerleşen öğrenci yüzdelerinin karşılaştırması

6- 2016-2020 yılları arasında son 5 yılda Milli Eğitim Bakanlığ1 (MEB) tarafindan yapılan Fen Bilgisi Öğretmenliği, Biyoloji Öğretmenliği, Fizik Öğretmenliği ve Kimya Öğretmenliği atama saylları Tablo 6'da gösterilmiştir (MEB 2016; 2017; 2018; 2019; 2020). 
Tablo 6: 2016-2020 yılları arasında Fen Bilgisi, Biyoloji, Fizik ve Kimya branşlarında MEB öğretmen atama say1lar1

\begin{tabular}{|c|c|c|c|c|c|}
\hline Yil & $\begin{array}{c}\text { Atama } \\
\text { Dönemi }\end{array}$ & $\begin{array}{c}\text { Fen Bilgisi } \\
\text { Öğretmenliği } \\
\text { Atama Sayıları } \\
\text { (İlk Atama+Ek } \\
\text { Atama) (f) }\end{array}$ & $\begin{array}{c}\text { Biyoloji } \\
\text { Ö ğretmenliği } \\
\text { Atama Sayıları } \\
\text { (İlk Atama+Ek } \\
\text { Atama) (f) }\end{array}$ & $\begin{array}{c}\text { Fizik } \\
\text { Öğretmenliği } \\
\text { Atama Sayıları } \\
\text { (İlk Atama+Ek } \\
\text { Atama) (f) }\end{array}$ & $\begin{array}{c}\text { Kimya } \\
\text { Öğretmenliği } \\
\text { Atama Sayıları } \\
\text { (İlk Atama+Ek } \\
\text { Atama) (f) }\end{array}$ \\
\hline \multirow{3}{*}{2016} & 1.Dönem & 1393 & 695 & 398 & 428 \\
\hline & 2.Dönem & 587 & 154 & 156 & 143 \\
\hline & Toplam & 1980 & 849 & 554 & 571 \\
\hline \multirow{3}{*}{2017} & 1.Dönem & $1003+54$ & $287+14$ & $239+14$ & $226+13$ \\
\hline & 2.Dönem & 15 & 14 & 10 & 10 \\
\hline & Toplam & 1072 & 315 & 263 & 249 \\
\hline \multirow{3}{*}{2018} & 1.Dönem & $1095+10$ & 68 & $132+4$ & $157+2$ \\
\hline & 2.Dönem & - & - & - & - \\
\hline & Toplam & 1105 & 68 & 134 & 159 \\
\hline \multirow{3}{*}{2019} & 1.Dönem & 919 & 70 & 235 & 190 \\
\hline & 2.Dönem & $1149+2$ & 90 & $250+2$ & $285+1$ \\
\hline & Toplam & 2070 & 160 & 487 & 476 \\
\hline \multirow{3}{*}{2020} & 1.Dönem & $1002+4$ & 93 & $156+2$ & $151+2$ \\
\hline & 2.Dönem & $1026+4$ & $94+2$ & $151+1$ & $154+1$ \\
\hline & Toplam & 2036 & 189 & 310 & 308 \\
\hline \multicolumn{2}{|c|}{ Genel Toplam (f) } & 8263 & 1581 & 1748 & 1763 \\
\hline
\end{tabular}

Tablo 6'ya göre son 5 yilda 2018 yll hariç diğer tüm yıllarda 2 dönemde öğretmen atamalarının yapıldığı sonucuna ulaşılmaktadır. Fen bilgisi öğretmenliğinin son 5 yıl içerisindeki öğretmen atama sayıları incelendiğinde 2016 yllında toplam 1980, 2017 yllında 1072, 2018 y1lında 1105, 2019 yllında 2070 ve 2020 yllında ise 2036 olduğu görülmektedir. Son 5 yılda MEB tarafindan ataması yapilan fen bilgisi öğretmen sayısının hemen hemen her geçen yil artış göstererek genel toplamı 8263 olarak hesaplanmıştır. Biyoloji öğretmenliğinin son 5 yll içerisindeki öğretmen atama sayllan incelendiğinde bu say1 2016 yllında 876 iken bu say1 2017'de 315'e 2018'de ise 68'e kadar düşmüştür. 2019 yll biyoloji öğretmeni atamasında bu sayı 160, 2020 yllında ise 189 olarak yapılmıştır. 5 yll içerisindeki genel toplam hesaplandığında MEB tarafından 1581 biyoloji öğretmeninin ataması yapılmıştır. Fizik öğretmenliğinin son 5 ylldaki atama sayıları incelendiğinde; 2016 yllında toplam 554, 2017 yllında 263, 2018 yllında 134, 2019 yllinda 487 ve 2020 yılında 310 olduğu görülmektedir. Son 5 yılda MEB tarafindan fizik öğretmeni olarak ataması yapılan öğretmen sayıs1 1748 olarak hesaplanmıştır. Kimya öğretmenliğinin son 5 ylldaki atama sayıları incelendiğinde 2016 yllında 571 olan öğretmen sayıs1, 2017 yllında 249'a, 2018 yllında ise 159'a düşürülmüştür. 2019 yllında 476'ya yükseltilen öğretmen atama sayısı 2020'de 308 olarak belirlenmiştir. Son 5 yılda Türkiye genelinde MEB tarafından ataması yapılan genel toplamdaki kimya öğretmeni sayısı 1763 olarak hesaplanmıştır. Branşlar bazında atama sayıları birbirine yakınlık gösteren biyoloji, fizik ve kimya branşlarında biyoloji öğretmeni atama sayılarının fizik ve kimya branşlarına göre kıyaslandığında oldukça az olduğu görülmektedir.

\section{Sonuç, Tartışma ve Öneriler}

2016-2020 ylllarına ait fen bilgisi öğretmenliği, biyoloji öğretmenliği, fizik öğretmenliği ve kimya öğretmenliği programlarının bulunduğu üniversiteler, kontenjan saylları ve YKS sonuçlarına göre yerleşen öğrenci sayılarının incelendiği çalışmanın sonuçlarına göre son yıllarda ilgili programların tamamında genel kontenjan sayısında azalma gözlenmiştir. 2016-2017 yıllarında fen bilgisi öğretmenliği programının genel kontenjan sayısı 4409 iken bu sayı her yil azaltılarak 5 yılin sonunda 2581'e kadar gerilemiş̧ir. Benzer şekilde biyoloji öğretmenliği programında 2016-2018 yıllarında 231 olan genel kontenjan sayısı 2020 de 147'ye; kimya ögrretmenliği programında ise 2016-2018 yllarında 273 olan genel kontenjan sayıs1 2020'de 189'a gerilemiştir. Fizik öğretmenliği programında ise 2016 yllında 168 olarak belirlenen genel kontenjan sayısında diğer branşlardan farklı olarak 2017-2018 yıllarında 189'a yükseltilmiştir ancak beklenen doluluk oranına sahip olamayınca 2019 ve 2020 yıllarında yeniden 168'e düşürülmüştür. 2017 yılında öğrencilerin YKS sonuçlarına göre öğretmenlik programlarının tercihinde ilgili puan türünde yapılan başarı 
sıralamasında en fazla 240 bininci olma şartının getirilmesine bağlı olarak kontenjanların doluluk oranlarının düşmesine neden olduğu düşünülürken, 2018 yllında bununla bağlantılı olarak genel kontenjan sayılarının da azaltıldığı görülmektedir. 2018 yılında YKS başarı sıralaması şartı biraz da esnetilerek en düşük 300 bininci olması şartına yükseltilmesine rağmen fen bilimleri öğretmenliği programlarının her branşında yine bir önceki yıldaki gibi tam doluluk sağlanamadığı anlaşılmaktadır. Üniversitelerin doluluk oranlarının dikkate alınarak her yıl güncellenen kontenjan sayılarının, 2019 yılında yine azaltıldığı ancak programlara yerleşen öğrenci sayılarında artışın olduğu gözlemlenmiştir. 2020 yllında oldukça düşürülen kontenjan sayılarına yeniden tam doluluk oranlarına ulaşması nedeniyle 2021 yilı itibari ile yeniden bir kontenjan artırımının yapılıp yapılmayacağı ilerleyen tarihlerde belli olacaktır.

Son 5 y1lda genel kontenjan sayısı toplamı ve ilgili programlara yerleşen toplam öğrenci sayıları incelendiğinde; 17371 kontenjana sahip fen bilgisi öğretmenliği programına 14256 öğrenci; 1029 kontenjana sahip biyoloji öğretmenliği programına 831 öğrenci, 882 kontenjana sahip fizik öğretmenliği programına 747 öğrenci ve 1239 kontenjana sahip kimya öğretmenliği programına 951 öğrenci yerleşmiştir.

MEB tarafindan öğretmen ihtiyacına göre yapılan atama sayılarının son 5 yıldaki genel toplamı incelendiğinde; 8263 fen bilgisi, 1581 biyoloji, 1748 fizik ve 1763 kimya öğretmeninin atamasının yapıldı̆̆1 belirlenmiştir. Yıllara göre branş bazındaki MEB atama sayıları incelendiğinde fen bilgisi öğretmenliği hariç diğer branşlarda en yüksek atama sayısı 2016 yılında olmuştur. 2017 ve 2018 yıllarının atama sayıları incelendiğinde ise hızlı bir düşüş gösteren rakamların yeniden 2019 ve 2020 yllarında arttığı görülse de biyoloji, fizik ve kimya branşlarındaki öğretmen atama sayıları genel olarak çok düşük sayılarda yapılmaktadır. Fen bilgisi öğretmenliği için 2016 yılında 1980 öğretmen ataması yapılırken, 2017 ve 2018 yıllarında neredeyse yarı oranda atama sayıları azaltılmış, 2019 ve 2020 yıllarında yeniden iki katına ulaşmıştır. Son 5 yllın verilerine göre ülkemizde fen bilgisi öğretmenliği bölümüne yerleştirilen öğrenci sayısındaki azalış ve öğretmen atama sayılarındaki artış dikkate alındığında ilerleyen yıllarda üniversitelerdeki kontenjan sayılarının yeniden artırılabileceği düşünülmektedir. Ortaöğretim öğretmenliklerine yönelik olan branşların üniversiteye öğrenci yerleştirme sayıları da dikkate alındığında aslında sayısal verilerin atama sayıları ile doğru orantılı olduğu sonucunu göstermektedir. Orantısız olarak artan sayılardan dolayı üst kurumlarca ihtiyaç fazlası olarak değerlendirildiği düşünülen fen bilimleri öğretmenliklerinin eğitim fakültesi kontenjanlarında azaltılması ile her geçen yıl önemini yitirerek taleplerin azalmasına neden olabileceğini düşündürmektedir. Bunun kaynakları arasında fen fakültesi mezunlarına ve son sınıf öğrencilerine pedagojik formasyon sertifika programına kayıt yaptırarak öğretmen olma hakkının verilmesinden kaynaklanıp kaynaklanmadığı da ayrı araştırmalarla incelenmelidir.

Günlük yaşantımız ile doğrudan ilişkili olan fen bilimleri derslerinin öneminin 2020 yılından bu zamana daha da iyi anlaşıldığı düşünülmektedir. Öyle ki varlığı ancak laboratuvar ortamlarında tespit edilebilen bir virüsün, Covid-19, dünyadaki tüm insanlığı nasıl olumsuz etkilediği ve halen de bu etkilerinin nasıl devam ettiği görülmektedir. Fen bilimleri dersleri bilindiği üzere temel bilim derslerinden olup hayatımızda yaşadığımız pek çok olay ile doğrudan ilişkilidir. Gerek ilköğretim döneminde gerekse ortaöğretim döneminde etkili bir fen öğretiminin nitelikli öğretmenler aracılı̆̆ıla sağlanması için bu bölümlere her daim ihtiyaç duyulduğu bilinen bir gerçektir (Magnusson ve ark., 1999). Ülkemizde öğretmen niteliğinin artırılmasına yönelik öğretmen adaylarının seçiminde, yetiştirilmesinde, istihdamında ve hizmetiçi eğitim faaliyetlerinin tamamını kapsayan bütünsel reformların yapılması gerektiği önerilmektedir (Mete, 2013). Ayrıca nitelikli öğretmenlerin yetiştirilmesi amacıyla Eğitim Fakülteleri’nde ilgili programların kontenjan sayılarının ve ögretmen atama sayılarının uygun oranlarda artırılması, pedagojik formasyon sertifika programlarının ise kaldırılması önerilmektedir.

\section{Extended Abstract}

It is a known fact that teachers constitute the most important and indispensable element of education to increase the quality of education system and to reach the international standards. In order to train teachers with qualified features, it is necessary to develop and increase the professional competencies before and during the service (Şişman, 2000). Especially in the pre-service period, education faculties have 
important duties in order to train prospective teachers as individuals with both high level of field and pedagogical knowledge with new century skills.

Science education, which is one of the basic fields of education is extremely important for all students and individuals. It takes place at every level of our education system with the spiral program from primary education to secondary education. For this reason it is necessary not only to provide students with theoretical knowledge in science courses but also to train them who assimilate knowledge, especially blended with new century skills.

In our country, Science education programs are carried out in the Department of Mathematics and Science Education with the divisions of Science Education, Biology Education, Physics Education and Chemistry Education. While the division of science education program aims to train teachers for primary school students; biology, physics and chemistry education programs aim to train teachers for secondary school students.

1- In this study it is aimed to examine the general situation of the Science Education Programs of all universities in Turkey about the last 5 years. In this context, research questions were determined as follows:

2- What is the general situation of universities with division of science education program: their quotas, the number and the percent of students registered as a result of the first and additional placement of OSYM between the years of 2016-2020?

3- What is the general situation of universities with division of biology education program: their quotas, the number and the percent of students registered as a result of the first and additional placement of OSYM between the years of 2016-2020?

4- What is the general situation of universities with division of physics education program: their quotas, the number and the percent of students registered as a result of the first and additional placement of OSYM between the years of 2016-2020?

5- What is the general situation of universities with division of chemistry education program: their quotas, the number and the percent of students registered as a result of the first and additional placement of OSYM between the years of 2016-2020?

6- What is the general comparison of all science education programs on the basis of branches between the years of 2016-2020?

7- What are the number of Ministry of Education appointments of all science education programs between the years of 2016-2020?

In accordance with the general purpose, document analysis method, the first placement and additional placement tables announced by OSYM (Measuring, Selection and Placement Center) for the years of 2016-2020, was used in the study and the results of all science education programs data were organized according to the content analysis tecnique.

Regarding the divisions of science education, biology education, physics education and chemistry education were organized separately in which universities in our country has these programs, the number of their general quotas, the number of students placed in them and the occupancy rates. As a result of the examination, the general quota of all science education programs has decreased considerably in the last 5 years. While the general quota for the division of science education program was decresed from 4409 to 2581, for biology education program was decreased from 231 to 147, for chemistry education was decresed from 273 to 189. In the physics program the quota of 168 was inreased to 189 for two years but in the last two years it was again decreased to 168 .

The occupancy rates of the students who were placed in these relevant programs in 2017 and 2018 were decreased with the success ranking condition that was implemented after 2017, which was almost $100 \%$ in 2016 in all branches of science education but it was started to increase in 2019 and the occupancy rate reached full capacity again as of 2020. The number of teacher appointments made by the Ministry of National Education (MEB) for science teachers was also examined by limiting it to the same years.

Especially when the data of the last 5 years for the purpose of the study are all examined, it is thought that the number of quotas in universities may be increased again or may be opened with some new science education divisions into the education faculties in the coming years, as a result of decreasing the quotas of 
students placed in all science education departments and increasing the number of teacher appointments in our country.

Keywords: Science education programs, Undergraduate quotas, Program occupancy rates, Teacher appointments

\section{Kaynakça}

Aydın, B. (2003). Bilgi toplumu oluşumunda bireylerin yetiştirilmesi ve matematik öğretimi. Pamukkaale Üniversitesi Ë̈itim Fakültesi Dergisi, 2(14), 183-190.

Bowen, G. A. (2009). Document analysis as a qualitative research method. Qualitative Research Journal, $9(2), 27-40$.

Gray, A. (2016). The 10 skills you need to thrive in the fourth industrial revolution. World Economic Forum.https://www.weforum.org/agenda/2016/01/the-10-skills-you-need-to-thrive-in-the-fourthindustrial-revolution/ adresinden erișildi.

Magnusson, S., Krajcik, J. \& Borko, H. (1999). Nature, sources and development of pedagogical content knowledge for science teaching. J. Gess-Newsome and N.G. Lederman (Ed.), Examining Pedagogical Content Knowledge içinde (s. 95-132). Dordrecht, The Netherlands: Kluwer Academic.

MEB (2016). Sö̌lesmeli ilk ve ek atama-alan bąl taban puanlar. http://atama.meb.gov.tr/sonuclar/arsiv/sayisal_veriler.asp?k_yil=2016\&k_tur=1\&Sonuc=Goster adresinden erișildi.

MEB (2017). Sö̊lesmeli ilk ve ek atama-alan bað̧ taban puanlar. http://atama.meb.gov.tr/sonuclar/arsiv/sayisal_veriler.asp?k_yil=2017\&k_tur=1\&Sonuc=Goster adresinden erişildi.

MEB (2018). Sözlesmeli ilk ve ete atama-alan bað̧ taban puanlar. http://atama.meb.gov.tr/sonuclar/arsiv/sayisal_veriler.asp?k_yil=2018\&k_tur=1\&Sonuc=Goster adresinden erișildi.

MEB (2019). Sözlessmeli ilk ve ek atama-alan bazll taban puanlar. http://atama.meb.gov.tr/sonuclar/arsiv/sayisal_veriler.asp?k_yil=2019\&k_tur=1\&Sonuc=Goster adresinden erişildi.

MEB (2020). Sözlesmeli ille ve ele atama-alan bąl taban puanlar. http://atama.meb.gov.tr/sonuclar/arsiv/sayisal_veriler.asp?k_yil=2020\&k_tur=1\&Sonuc=Goster adresinden erișildi.

Mete, Y. A. (2013). Güney Kore, Japonya, Yeni Zelanda ve Finlandiya’ da öğretmen yetiştirme ve atama politikalar1. Turkish Studies, 8(12), 859-878.

OECD. (2016). PISA 2015 Results (Volume I): Excellence and equity in education. http://dx.doi.org/10.1787/9789264266490-en adresinden erişildi.

OECD.(2018). The future of education and skills: Education 2030. https://www.oecd.org/education/2030/E2030\%20Position\%20Paper\%20 adresinden erişildi.

ÖSYM. (2016a). Tablo-4 Merkęzi yerleștirme ile ögrenci alan yüksekëğretim lisans programlar. https://dokuman.osym.gov.tr/pdfdokuman/2016/LYS/Yerlestirme_Tablo-

4_MinMax_Lisans10082016.pdf adresinden erişildi.

ÖSYM. (2016b). Tablo-4 Ek yerlestirme ile öğrenci alan yükesekögretim lisans programlar. https://dokuman.osym.gov.tr/pdfdokuman/2016/OSYS/EKYER/Tablo-4_lisansek05092016.pdf adresinden erişildi.

ÖSYM. (2017a). 2017 Yüksekögrretion programlar ve kontenjanlar kilavuðu. https://dokuman.osym.gov.tr/pdfdokuman/2017/OSYS/LYS/KONTENJANKILAVUZ18072017.pdf adresinden erişildi.

ÖSYM. (2017b). Tablo-4 Merkęৃi yerleștirme ile ögrrenci alan yüksekëğretim lisans programlar. https://dokuman.osym.gov.tr/pdfdokuman/2017/OSYS/LYS/TABLO-4_14072017.xls adresinden erişildi. 
ÖSYM. (2017c). Tablo-4 Ek yerlestirme ile ögrrenci alan yükesekögrretim lisans programlarl. https://dokuman.osym.gov.tr/pdfdokuman/2017/OSYS/EK/TABLO4lisanseky12092017.pdf adresinden erişildi.

ÖSYM. (2018a). 2018 Yüksekögretim programlar ve kontenjanlar kalavuzu. https://dokuman.osym.gov.tr/pdfdokuman/2018/YKS/KONTKILAVUZ6082018.pdf adresinden erișildi.

ÖSYM. (2018b). Tablo-4 Merkęৃ yerleştirme ile ögrenci alan yükesekëgrretim lisans programlar. https://dokuman.osym.gov.tr/pdfdokuman/2018/YKS/YER/Tablo4MinMax_31082018.pdf adresinden erișildi.

ÖSYM. (2018c). Tablo-4 Ek yerlestirme ile ögrenci alan yüksekëgrretim lisans programlar. https://dokuman.osym.gov.tr/pdfdokuman/2018/YKS/EK/TABLO-4_28092018.pdf adresinden erişildi..

ÖSYM. (2019a). 2019 Yükesekögretim programlar ve kontenjanlar kulavuzu. https://dokuman.osym.gov.tr/pdfdokuman/2019/YKS/kontkilavuz_18072019.pdf adresinden erişildi.

ÖSYM. (2019b). Tablo-4 Merkęi yerleştirme ile ögrrenci alan yükeseköğretim lisans programlar. https://dokuman.osym.gov.tr/pdfdokuman/2019/YKS/tablo4_06082019.pdf adresinden erișildi.

ÖSYM. (2019c). Tablo-4 Ek yerlestirme ile ögrenci alan yükesekögrretim lisans programlar. https://dokuman.osym.gov.tr/pdfdokuman/2019/YKS/EK/tablo4_19092019.pdf adresinden erişildi.

ÖSYM. (2020a). 2020 Yüksekögretim programlar ve kontenjanlar kalavuzu. https://dokuman.osym.gov.tr/pdfdokuman/2020/YKS/tkilavuz13082020.pdf adresinden erişildi.

ÖSYM. (2020b). Tablo-4 Merkęৃi yerlestirme ile ögrenci alan yükesekögretim lisans programlar. https://dokuman.osym.gov.tr/pdfdokuman/2020/YKS/tablo4_13082020.xls adresinden erişildi.

ÖSYM. (2020c). Tablo-4 Ek yerlestirme ile ögrenci alan yükesekögrretim lisans programlar. http://dokuman.osym.gov.tr/pdfdokuman/2020/YKS/EK/tablo4_17092020.xls adresinden erişildi.

Sönmez, V. \& Alacapınar, F. G. (2014). Örneklendirilmiş bilimsel araștırma yöntemleri. Ankara: Anı Yayincilik.

Şisman, M. (2009). Öğretmen Yeterlilikleri: Modern Bir Söylem ve Retorik. İnönü Üniversitesi Eğitim Fakültesi Dergisi, 10(3), 63-82.

TIMSS (2018). TIMSS Türkiye resmi internet sitesi. http://timss.meb.gov.tr/ adresinden erişildi.

Wach, E. (2013). Learning about qualitative document analysis. IDS Practice Paper in Brief, 1-10.

Yıldırım, A.\& Şimşek, H. (2006). Sosyal bilimlerde nitel araștırma yöntemleri. (5. Baskı), Ankara: Seçkin Yayinc1lik.

\section{Ek: İçerik Analizi Yapılan Dokümanlar Listesi}

1- MEB (2016). Sözlesmeli ilk ve ele atama-alan bazll taban puanlar. http:/ /atama.meb.gov.tr/sonuclar/arsiv/sayisal_veriler.asp?k_yil=2016\&k_tur=1\&Sonuc=Goster adresinden erişildi.

2- MEB (2017). Sözlesmeli ilk ve ek atama-alan bazll taban puanlar. http:/ /atama.meb.gov.tr/sonuclar/arsiv/sayisal_veriler.asp?k_yil=2017\&k_tur=1\&Sonuc=Goster adresinden erişildi.

3- MEB (2018). Sözleşmeli ilk ve ele atama-alan bąll taban puanlar. http:/ /atama.meb.gov.tr/sonuclar/arsiv/sayisal_veriler.asp?k_yil=2018\&k_tur=1\&Sonuc=Goster adresinden erişildi.

4- MEB (2019). Sözlesmeli ilk ve ek atama-alan bazll taban puanlar. http:/ /atama.meb.gov.tr/sonuclar/arsiv/sayisal_veriler.asp?k_yil=2019\&k_tur=1\&Sonuc=Goster adresinden erişildi.

5- MEB (2020). Sözleşmeli ilk ve ek atama-alan bazll taban puanlar. http:/ /atama.meb.gov.tr/sonuclar/arsiv/sayisal_veriler.asp?k_yil=2020\&k_tur=1\&Sonuc=Goster adresinden erişildi. 
6- ÖSYM. (2016a). Tablo-4 Merkezi yerlestirme ile ögrenci alan yükseköğretim lisans programları. https://dokuman.osym.gov.tr/pdfdokuman/2016/LYS/Yerlestirme_Tablo4_MinMax_Lisans10082016.pdf adresinden erişildi.

7- ÖSYM. (2016b). Tablo-4 Ek yerlestirme ile ögrenci alan yükesekögrretim lisans programlar. https://dokuman.osym.gov.tr/pdfdokuman/2016/OSYS/EKYER/Tablo4_lisansek05092016.pdf adresinden erişildi.

8- ÖSYM. (2017b). Tablo-4 Merkezi yerleștirme ile ögrenci alan yükesekögrretim lisans programlar. https://dokuman.osym.gov.tr/pdfdokuman/2017/OSYS/LYS/TABLO-4_14072017.xls adresinden erişildi.

9- ÖSYM. (2017c). Tablo-4 Ek yerleştirme ile ögrenci alan yükesekëğretim lisans programlar. https://dokuman.osym.gov.tr/pdfdokuman/2017/OSYS/EK/TABLO4lisanseky12092017.pdf adresinden erişildi.

10- ÖSYM. (2018b). Tablo-4 Merkęi yerlestirme ile ögrenci alan yükeseköğretim lisans programlar. https://dokuman.osym.gov.tr/pdfdokuman/2018/YKS/YER/Tablo4MinMax_31082018.pdf adresinden erișildi.

11- ÖSYM. (2018c). Tablo-4 Ek yerleştirme ile ögrenci alan yükesekëğretim lisans programları. https://dokuman.osym.gov.tr/pdfdokuman/2018/YKS/EK/TABLO-4_28092018.pdf adresinden erișildi..

12- ÖSYM. (2019b). Tablo-4 Merkezi yerlestirme ile ögrenci alan yükesekögrretim lisans programlar. https://dokuman.osym.gov.tr/pdfdokuman/2019/YKS/tablo4_06082019.pdf adresinden erişildi.

13- ÖSYM. (2019c). Tablo-4 Ek yerlestirme ile ögrenci alan yükesekögretim lisans programlar. https://dokuman.osym.gov.tr/pdfdokuman/2019/YKS/EK/tablo4_19092019.pdf adresinden erişildi.

14- ÖSYM. (2020b). Tablo-4 Merkezi yerleştirme ile ögrenci alan yükseköğretim lisans programlart. https://dokuman.osym.gov.tr/pdfdokuman/2020/YKS/tablo4_13082020.xls adresinden erişildi.

15- ÖSYM. (2020c). Tablo-4 Ek yerlestirme ile ögrenci alan yükesekëgrretim lisans programları. http://dokuman.osym.gov.tr/pdfdokuman/2020/YKS/EK/tablo4_17092020.xls adresinden erişildi. 